$$
\text { by }
$$

Jacob Sayre Stickann, BA in Photography, Columbia College Chicago, 2004

$$
\begin{gathered}
\text { A thesis } \\
\text { presented to Ryerson University } \\
\text { and }
\end{gathered}
$$

George Eastman House International Museum of Photography and Film

in partial fulfillment of the

requirements for the degree of

Master of Arts

in the Program of

Photographic Preservation and Collections Management

Toronto, Ontario, Canada, 2009

(C) Jacob Sayre Stickann 2009 
I hereby declare that I am the sole author of this thesis.

I authorize Ryerson University to lend this thesis to other institutions or individuals for the purpose of scholarly research.

I further authorize Ryerson University to reproduce this thesis by photocopying or by other means, in total or in part, at the request of other institutions or individuals for the purpose of scholarly research. 


\title{
CREATING AN ACQUISITION REPORT FOR SIX PORTFOLIOS FROM THE SCHOOL OF PHOTOGRAPHIC ARTS AND SCIENCES AT ROCHESTER INSTITUTE OF TECHNOLOGY
}

\author{
Master of Arts, 2009 \\ Jacob Sayre Stickann \\ Photographic Preservation and Collections Management \\ Ryerson University and George Eastman House
}

\begin{abstract}
Six portfolios produced between the years 1987 and 1992 have been offered to the Department of Photographs at George Eastman House. Assembled by the faculty and staff of the School of Photographic Arts and Sciences (SPAS) at Rochester Institute of Technology (RIT), they contain a total of 169 photographic prints of various processes made by 52 participants. An acquisition report is needed in order for the acquisition committee to understand the portfolios and make an informed decision as to whether they should be acquired for the collection. The main focus of this thesis is an acquisition report for the six portfolios. It also includes a brief history of photographic education at RIT followed by an overview of the portfolios and their production, which relies on correspondence with many of the participants.
\end{abstract}




\section{Acknowledgements}

This thesis would have not been possible without the help and effort of many people. I would like to thank Vid Ingelevics, my thesis advisor, for his guidance and encouragement throughout the project. Thanks to Alison Nordström for her suggestions and input. I must also acknowledge and give many thanks to the staff at George Eastman House, especially Jamie Allen, Taina Meller and Wataru Okada.

I am grateful for the assistance of those who participated in the portfolios with whom I was able to correspond. Special thanks go to Michael Peres, who contributed much time and effort to this project, and Bob Kayser, who welcomed me into his home. I would also like to thank Jody Sidlauskas and Becky Simmons, at RIT Special Collections, for their assistance and patience.

Finally, I would like to thank all my friends and family who supported and encouraged me throughout the entire project. 
Introduction

Section I

A Brief History of Rochester Institute of Technology

and the School of Photographic Arts and Sciences

History and Overview of the Portfolios

8

Section II

Research Process

Further Research

Section III

Importance of an Acquisition Report

Acquisition Report

\section{Appendix A}

Biographies of the Participants

\section{Appendix B}

Inventory of the Six Portfolios

Bibliography

\section{Images}

figure 1. Amy Friend, Untitled, c. 1992

figure 2. Nancy M. Stuart, Alan, 1986

figure 3. Nancy M. Stuart, Untitled, c. 1992 
figure 4. Kathleen Collins, Untitled, May 1987

figure 5. Kathleen Collins, Untitled, c. 1989

figure 6. Dan Larkin, Untitled, c. 1990

figure 7. Dan Larkin, Untitled, c. 1992

figure 8. Howard LeVant, Untitled, c. 1988

figure 9. Willie Osterman, Untitled, c. 1987

figure 10. Willie Osterman, Untitled, 1989

figure 11. Skip Battaglia, Untitled, $1989 \quad 18$

figure 12. Michael Peres, Untitled, c. 1987

figure 13. Michael Peres, Where Bone Meets Cartilage x 350, c. 1990 


\section{Introduction}

The focus of my thesis project is an acquisition report I have written for the Department of Photographs at George Eastman House. It concerns six portfolios assembled by members of the faculty and staff of the School of Photographic Arts and Sciences (SPAS) at Rochester Institute of Technology (RIT) from the years 1987 through 1992. This thesis allowed me to produce something practical for the museum and to have the opportunity to work with original, contemporary photographic objects. I intend the acquisition report to provide the acquisition committee of the Department of Photographs with a better understanding of the portfolios and their participants. I also intend that this thesis function as a compendium for the portfolios, their participants, and their production as well as contribute information to the RIT library regarding copies of the portfolios they have in their collection.

The thesis is divided into three sections, each of which has two parts. In the first section, I begin by presenting a brief history of RIT and photographic education at that institution, providing a background on the institution that produced the portfolios. Next, I offer an overview of the portfolios and their production, putting them into context with correspondence and interviews with their participants.

In the second section, I start by describing my research methodology concerning the portfolios and acquisition report. Then I discuss possible further research to be carried out by those interested in RIT or the individual participants.

The third section contains a brief summary of the function and importance of an acquisition report, followed by a copy of the acquisition report to be given to members of 
the acquisition committee. This allows them to make an informed decision as to whether the six portfolios should be acquired for the collection at Eastman House. Both appendices are extended components of this acquisition report. Appendix A offers a brief biography of each participant, while Appendix B provides a complete inventory of all six portfolios. 


\section{Section I}

\section{A Brief History of Rochester Institute of Technology and the School of}

\section{Photographic Arts and Sciences}

Rochester Institute of Technology has its roots in a technical institution almost as old as the city of Rochester itself: the Athenaeum, founded by Colonel Nathaniel Rochester and other community leaders in 1829 , only twelve years after Rochester was incorporated as a village. ${ }^{1}$ Dane R. Gordon, in his extensive history of RIT, describes the Athenaeum's founding being necessitated by society's growing demand for "practical or useful training" to meet its needs but which was also "intentionally set within a humanistic context.", Gordon believes that even to this day the Institute "has maintained that context in the general sense that technical, professional instruction alone does not constitute a complete education." ${ }^{3}$ This philosophy of technical training "within a humanistic context" is reflected in RIT's position at the forefront of photographic technology, along with the wide range of photographic disciplines with which it presently engages.

Over the next several decades, the Athenaeum merged with many other associations and institutions. In 1891, the Athenaeum and Mechanics Institute merged to form the Rochester Athenaeum and Mechanics Institute. Captain Henry Lomb, of the

\footnotetext{
${ }^{1}$ Dane R. Gordon, Rochester Institute of Technology: Industrial and Educational Innovation in an American City 1829-2006, $2^{\text {nd }}$ ed. (Rochester, NY: RIT Press, 2007), 44. ${ }^{2}$ Ibid., 8.

${ }^{3}$ Ibid.
} 
Bausch and Lomb Optical Company, as well as other Rochester businessmen, had founded the Mechanics Institute in 1885 in order to supply the local industry with a labor force. $^{4}$

From its very start, George Eastman was involved with the Institute. He was a member of the Board of Directors from 1890 until 1915 and its Chairman for those last two years. ${ }^{5}$ His very first charitable contribution was fifty dollars to the Mechanics Institute in $1887,{ }^{6}$ and he continued to contribute funds to the Institute throughout his twenty-five years as a member of the Board. On October 15, 1900, the cornerstone for the new Eastman Building was laid. Eastman donated both the money, worth over $\$ 200,000$ at the time, for the land and the new building construction. ${ }^{7}$

By the turn of the century, the local establishment of companies such as Eastman Kodak and Bausch and Lomb had made Rochester a center for photography. Most likely due to the encouragement of Eastman and other local business leaders, and as part of a momentum that began at the turn of the century, ${ }^{8}$ the Institute began to offer day and evening classes in photography in January $1902 .{ }^{9}$

In her dissertation, "History of Photographic Education in Rochester, New York, 1960 - 1980," Nancy M. Stuart states that the School of Photographic Arts and Sciences "grew out of a vocational education model with the mission of supplying local industry

\footnotetext{
${ }^{4}$ Ibid., 44.

${ }^{5}$ Ibid., 135.

${ }^{6}$ Ibid., 51.

${ }^{7}$ Ibid., 65 .

${ }^{8}$ Nathan Lyons, "History of Photographic Education with an Emphasis on its Development in the United States," in The Education of a Photographer, ed. Steven Heller and Adam B. Bell (New York: Allworth Press, 2006), 179.

${ }^{9}$ Nancy M. Stuart, "The History of Photographic Education in Rochester, New York, 1960-1980" (PhD diss., State University of New York at Buffalo, 2005), 65.
} 
with a qualified labor force." ${ }^{10}$ The influence of local industry upon the Institute led to the establishment of the School of Photography in 1930. Created at the request of the Eastman Kodak Company and other local industrial photographic interests, the school acted as a work-study program to supply a trained workforce. ${ }^{11}$ Eastman Kodak "loaned" Frederick F. Brehm to the school to teach part-time. C.B Neblette, another "loaned" employee of Eastman Kodak, followed him in $1931 .{ }^{12}$ Although still considered "on loan," Neblette became the first full-time faculty member in the School of Photography in $1936 .{ }^{13}$ That same year, following a growing trend of students showing interest in the professional, rather than technical, side of photography, the School instituted a three year program divided into two departments: Photographic Technology, which provided technological training, and Professional Photography, which provided commercial training in studio and advertising photography. ${ }^{14}$ This shift marked the origins of the evolution of the photographic curriculum, from vocational training with an emphasis on the strictly technical side of photography, to a wider range of approaches to photographic practice.

In 1944, the Rochester Athenaeum and Mechanics Institute became Rochester Institute of Technology. It began offering an Associate of Applied Science degree in 1950 and a Bachelor of Science degree in 1953. Accreditation through the Middle States

\footnotetext{
${ }^{10}$ Ibid., 67.

${ }^{11}$ William Soule Shoemaker. History of the School of Photographic Arts and Sciences: Prepared in Honor of the $50^{\text {th }}$ Anniversary of the Founding of That School (Rochester, NY: RIT, 1980), 1.

${ }^{12}$ Ibid., 1-2.

${ }^{13}$ Ibid., 3.

${ }^{14}$ Ibid., 3-4.
} 
Association of Colleges and Secondary Schools soon followed in $1958 .{ }^{15}$ Neblette eventually became head of the Department of Photographic Technology. In 1960, after the Institute was divided into colleges, he became both the Director of the School of Photography and the Dean of the College of Graphic Arts and Photography. ${ }^{16}$ His influence was instrumental in building and developing the new photography program at RIT. In History of the School of Photographic Arts and Sciences: Prepared in Honor of the $50^{\text {th }}$ Anniversary of the Founding of That School, William Shoemaker states that "Many consider Neblette one of, if not the first, truly great photographic educators in this country." $" 17$

Stuart observed 'it is RIT's applied science roots that formed the foundation of RIT's programs in photography," ${ }^{18}$ but the programs further broadened out from those roots after the introduction of the BFA program in 1960. Developed by Ralph Hattersley, Charles Arnold, and Minor White, the BFA brought art and humanism to a program that previously focused on the science and technical craft of the medium. In 1969, RIT's esteemed MFA program was also initiated.

In 1968, RIT relocated to its new campus in Henrietta and the School of Photography moved into the Frank E. Gannett Memorial Building. It also changed its name to the School of Photographic Arts and Sciences to emphasize its new focus on art as well as science. ${ }^{19}$ That same year, Neblette retired as Dean. ${ }^{20}$ He was replaced by Dr.

\footnotetext{
${ }^{15}$ Nancy M. Stuart, "The History of Photographic Education in Rochester, New York, 1960-1980" (PhD diss., State University of New York at Buffalo, 2005), 66.

${ }^{16}$ Ibid., Appendix V.

${ }^{17}$ Ibid., 19.

${ }^{18}$ Ibid., 35.

${ }^{19}$ Nancy M. Stuart, "The History of Photographic Education in Rochester, New York, 1960-1980" (PhD diss., State University of New York at Buffalo, 2005), 67.
} 
Lothar Engelmann, a German native trained as a chemist (and one of the participants in the portfolios). ${ }^{21}$

Throughout the 70s and 80s, education in the SPAS continued to expand. In 1973, the SPAS began to offer a BS in Biomedical Photographic Communication. In 1980, a BS in Film and Video was added. By the late 80s and early 90s, RIT was a leader in the field of photographic education with its innovative and diverse instruction. Digital technology was just making a foothold in photography as well as at RIT. "Digital photography was just beginning and we had a vague sense of what it was about," recalled Harvey Stein, who taught at RIT at the time. This new technology created uncertainty for some, was ignored by others, and piqued the interests of several members of the SPAS faculty. Loret Steinberg, a current professor at RIT, remembers the time as "simply a period of transition, leading to what we have now and the curriculum we currently teach." 22 With the onset of the digital revolution, the School of Photographic of Arts and Sciences would no longer be the same school; as photography evolved, the school evolved along with it.

Today the School of Photographic Arts and Sciences offers a BFA in Advertising Photography, Fine Art Photography, Photojournalism or Visual Media; a BS in Biomedical Photographic Communication or Imaging and Photographic Technology; and an MFA in Imaging Arts. The Film and Video Program has become a separate school in the College of Imaging Arts and Sciences under the name of the School of Film and Animation. The SPAS's website boasts of its "state of the art facilities and equipment for

\footnotetext{
${ }^{20}$ Nancy M. Stuart, "The History of Photographic Education in Rochester, New York, 1960-1980" (PhD diss., State University of New York at Buffalo, 2005), 69.

${ }^{21}$ Ibid., 71.

${ }^{22}$ Loret Steinberg, email to the author, July 10, 2009.
} 
students, including current digital \& film camera systems, color and black and white darkrooms, and school-wide high speed internet. ${ }^{, 23}$ The digital facilities are described as "without parallel among peer institutions" with "the most up to date hardware, software, and output technologies, color managed for comprehensive imaging and output."24 Photographic education at RIT remains internationally renowned and the degrees it offers, covering the technical, practical and artistic uses of photography, keep it at the forefront of the field.

\section{History and Overview of the Portfolios}

The portfolios were first produced in May 1987 under the direction of Michael Peres, who had been hired in 1986 to teach in the Biomedical Photographic Communications program. They were initiated as a print exchange amongst faculty and staff of the School of Photographic Arts and Sciences, what Peres called a "print swap and an opportunity to place a collection of faculty [and staff] work in the library's permanent collection." 25

"I thought it would be fun to collect people's pictures, so we just started sharing pictures and it was kind of fun and spontaneous," recalled Peres. "I was kind of new here and wanted to be involved." ${ }^{26}$ There were a total of nine editions produced, the first in May 1987 and the last in May 1997 (but which actually was collected from the years

\footnotetext{
${ }^{23}$ Rochester Institute of Technology, "School of Photographic Arts and Sciences: Facilities," http://cias.rit.edu/ (accessed June 22, 2009).

${ }^{24}$ Ibid.

${ }^{25}$ Michael Peres, e-mail message to author, May 1, 2009.

${ }^{26}$ Michael Peres, in discussion with the author, June 2, 2009.
} 
1995-1996). The first six editions of the portfolio were donated to Eastman House by RIT. They originally belonged to John Trauger, a Professor Emeritus in the School of Photographic Arts and Sciences, but were donated to RIT by Trauger's estate after he died in 2007. Because RIT already had copies of the portfolios, the decision was made to donate them to Eastman House.

Participation in the portfolios was strictly voluntary and did not include all the faculty and staff in the SPAS. Peres personally promoted the project through invitation, and he would then let those who chose to participate know how many prints to make and the deadline they had to be in by. The number of prints made by each participant was dictated by the number of participants with the addition of at least another three copies: one for the Library Archives, one for the Office of the Dean of the College, and one for Frank Cost, a Professor in the school of Print Media who printed the cover page for each portfolio. Thus, since there were 30 participants in the May 1987 portfolio, there were at least 33 copies of that edition of the portfolio produced.

The cover page of each portfolio listed the participants in that edition in alphabetical order. The text was written by Michael Peres, laid out and designed by Charles Arnold, and then given to Frank Cost, who hand-printed each cover page on a sheet of high-quality paper. As a result, the list of participants was not always accurate as some failed to submit work after committing to do so, and the cost and effort of updating the cover page was too prohibitive to allow a second printing.

The RIT library, in exchange for a copy of each portfolio, paid for the portfolio cases and interleaving paper. The material was all archival and bought for a discount 
from Light Impressions. The participants underwrote all the costs of the production and materials for the prints.

Participation began to wane in the last editions of the portfolios. The first two editions have 30 and 36 participants listed, while the last two editions have 21 and 16 , respectively. As the project progressed over the years, Peres described it as "like herding cats. ${ }^{27} \mathrm{He}$ had to chase people down to get their prints and sometimes even had to mail out prints submitted late to make sure they got in all of the portfolios. "It became too much like work," Peres recalled. "I didn't want to do work, I just wanted to exchange prints with colleagues. ${ }^{28}$ The gradual loss of interest and lack of commitment to the project is evident in the 1990 and 1992 editions of the portfolios, where two participants in each edition failed to contribute the prints they had agreed to submit. Doug Rea recalled that although he had signed up to participate in the 1990 portfolio, he was unable to contribute because he was busy producing the first of two international teleconferences on the emerging world of electronic photography, as well as dealing with an illness in the family. ${ }^{29}$

The general loss of interest in the portfolios was also due to a variety of other personal reasons among the faculty and staff, but time and cost were certainly two main factors. "It took up a lot of time - making 20 to 25 prints and I may have been busy with other things at the time," recalled Mark Haven on his reasons for not contributing to certain editions. ${ }^{30}$ It can be very time-consuming and expensive to produce 36 prints, especially with processes requiring significant darkroom time or with higher-cost

\footnotetext{
${ }^{27}$ Michael Peres, in discussion with the author, June 2, 2009.

${ }^{28}$ Ibid.

${ }^{29}$ Doug Rea, email to the author, July 12, 2009.

${ }^{30}$ Mark Haven, email to the author, July 30, 2009.
} 
materials, such as fiber-based paper or silver dye bleach paper. The portfolios were also assembled at an inconvenient time for the staff and faculty of RIT. People would sign up in March, but the deadline for prints and the portfolio assembly was in May when the end of the semester was also approaching. There were exams, grades, and summer workshops for which to prepare, so coordinating for a portfolio may have been a lower priority.

By the last edition, Michael Peres thought, "This is killing me."31 He was working on his own Master's degree, had young children and was trying to develop his own scholarly work in the biomedical field. Near the end, his own energy for the project waned, but he also admits that the lack of response from others may have come, in part, from him not pushing participation as hard as he had in the beginning. ${ }^{32}$

Despite petering out after nine years, the portfolios remain a testament to the diverse photographic interests, and "personal areas of exploration by each photographer," as stated on the cover pages. Many participants contributed to only a few of the portfolios. This may have been because they were only temporarily part of the faculty or staff. Amy Friend described the photograph she contributed as "part of another assignment and [that] was used in my personal portfolio." ${ }^{, 33}$ (See figure 1.) She contributed only to one portfolio because she was employed as Adjunct Faculty for only that one year. Greg Barnett contributed to only the first two editions of the portfolios but continues to work at RIT to this day. "The work was part of a series that I had been

\footnotetext{
${ }^{31}$ Michael Peres, in discussion with the author, June 2, 2009.

${ }^{32}$ Ibid.

${ }^{33}$ Amy Friend, email to the author, May 21, 2009.
} 
working on at the time[: 4" x 5", black-and-white] landscapes up in the Adirondacks," he said of the photographs he contributed. ${ }^{34}$

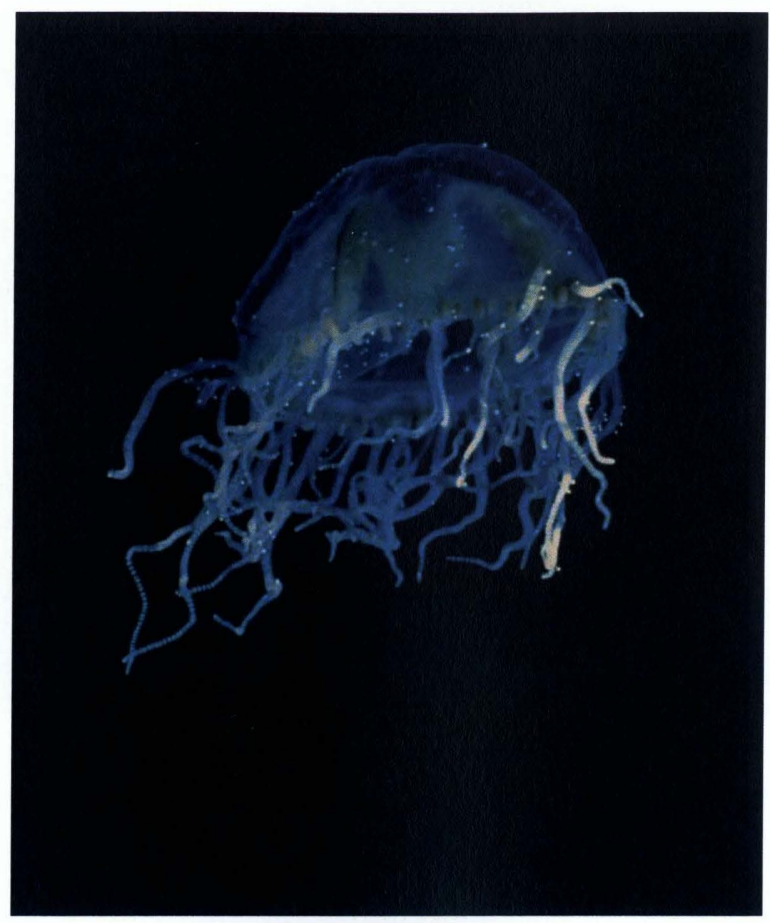

figure 1. Amy Friend, Untitled, c. 1992 (C) Amy Friend

Others, like Nancy M. Stuart, participated in most or all the portfolios. She was part of what Peres called the "nucleus" of individuals who participated every year. ${ }^{35}$ Her contributions to the first six editions are all portraits (see figure 2 and figure 3 ).

“Typically I would choose an image from a body of work that was very current. I do a lot of work with portraiture and tried to choose images that were more universal than about

${ }^{34}$ Greg Barnett, email to the author, May 14, 2009.

${ }^{35}$ Michael Peres, in discussion with the author, June 2, 2009. 
specific individuals. ${ }^{, 36}$ The work she contributed was all from a field of photography in which she specialized.

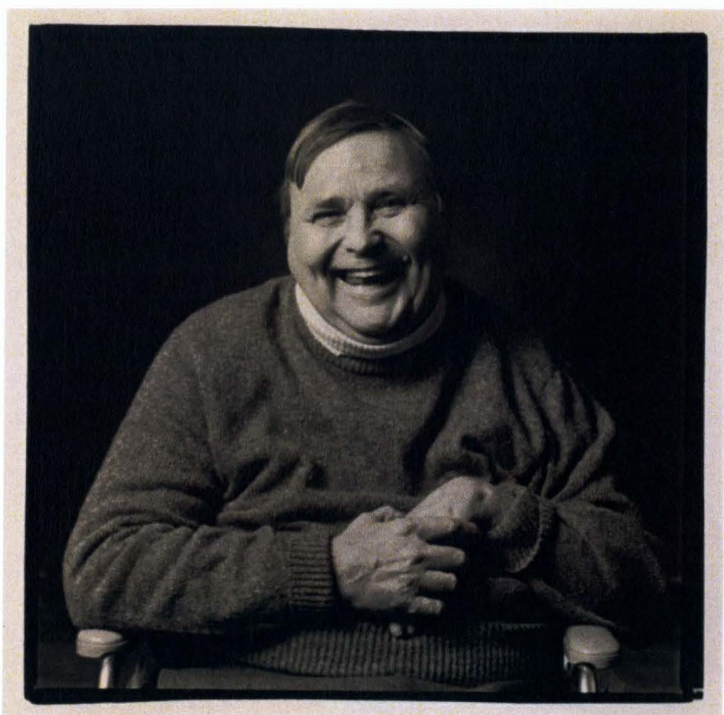

figure 2. Nancy M. Stuart, Alan, 1986 () Nancy M. Stuart

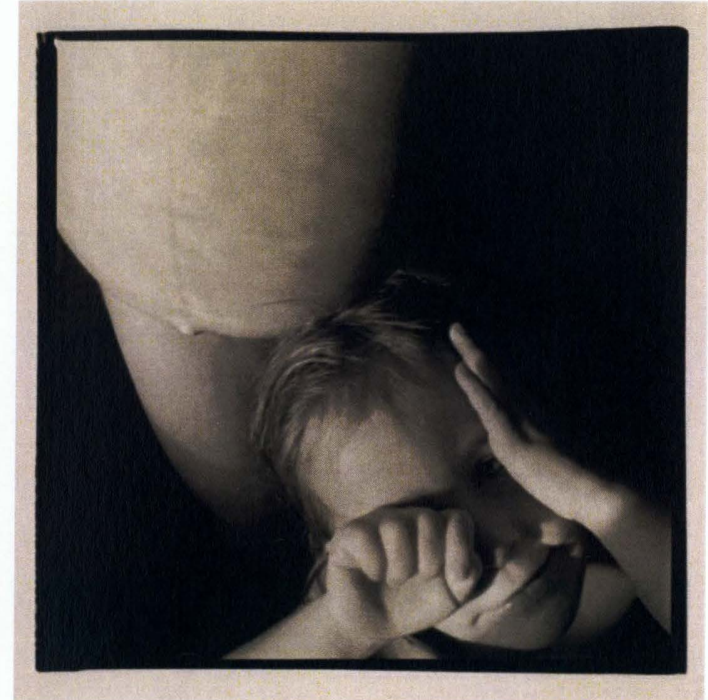

figure 3. Nancy M. Stuart, Untitled, c. 1992 (C) Nancy M. Stuart

Kathleen Collins contributed to the 1987 and 1989 portfolios but had different reasons for choosing her photographs for each year: "The image in the 1987 portfolio is of a Mexican street, taken with my Hasselblad camera. This was an image that was not shown in any exhibition nor was it part of a project [see figure 4]. I have photographed in Mexico a great deal over the years and my thesis project from RIT included a number of $5 \times 7$ contact prints of images from Mexico. I think I chose this particular image because it was one that did represent my work in general and I wanted to choose an image that might have some general appeal to a broad range of photographers." Regarding the photograph for the 1989 portfolio, she said, "The image of an industrial worker from Chicago would have been chosen as representing the work I was doing at the time [see

\footnotetext{
${ }^{36}$ Nancy M. Stuart, email to the author, May 14, 2009.
} 
figure 5]. That always seemed important to me. I was very involved in doing ongoing work, so currency was important. ${ }^{, 37}$

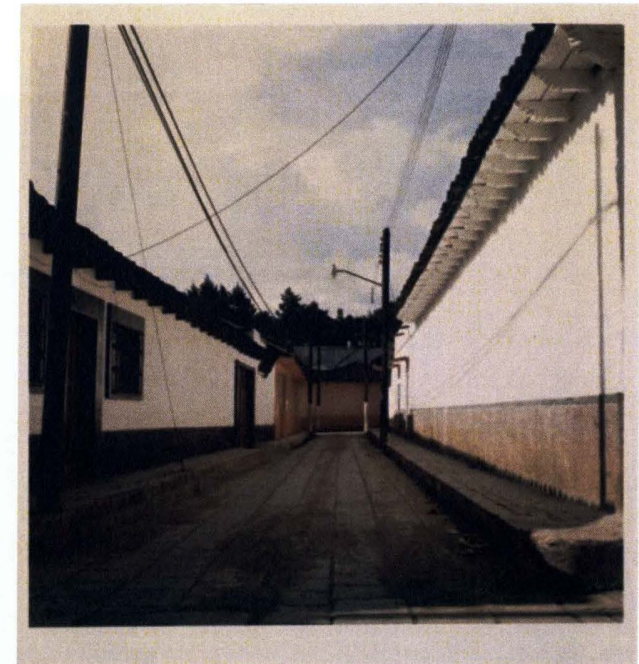

figure 4. Kathleen Collins, Untitled, May 1987 @ Kathleen Collins

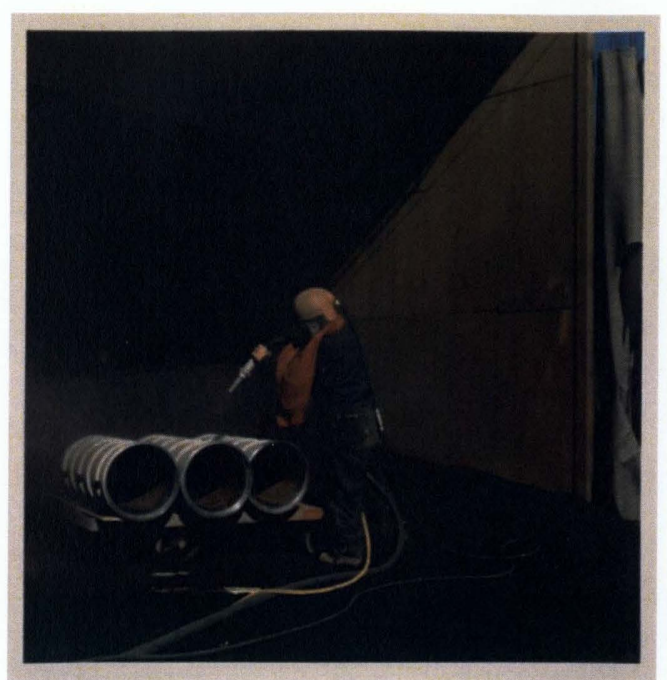

figure 5. Kathleen Collins, Untitled, c. 1989 @ Kathleen Collins

Dan Larkin also remembered his contributions as being current at the time the portfolios were made: "90 and 91 were both made on Cape Cod. It was an ongoing project that I finished more or less in '91 or '92 that I now refer to as 'Old Cape Cod." (See figure 6.) The three contributions Larkin made to the 1990, 1991, and 1992 portfolios not only showed ongoing projects but changes in his work: "The 1992 print marks a considerable shift in my work. This was during graduate school at Bard College (a summer residence program where I studied with Stephen Shore and John Divola among others from 1991-3.) I was utilizing a plastic "Diana" camera closer than minimum focusing distance, time exposures and color transparency film that I had "crossprocessed" into negatives and printed - the prints were very color saturated, had

\footnotetext{
${ }^{37}$ Kathleen Collins, email to the author, June 2, 2009.
} 
pronounced grain and were preferably printed large - at least 15 " x $15 . "$ It was a series of still lifes [sic] called 'Fruit, Vegetables and Maybe Candy' that explored lust and desire as manifested in all things edible." ${ }^{38}$ (See figure 7.)

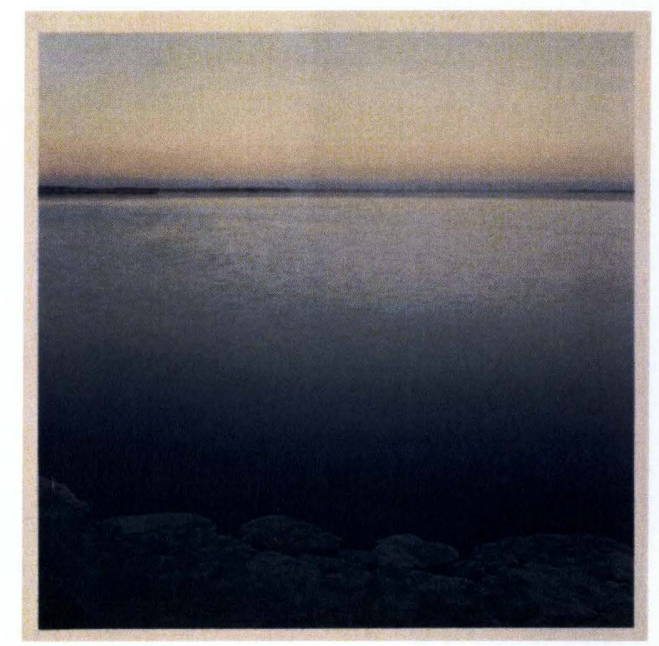

figure 6. Dan Larkin, Untitled, c. 1990 () Dan Larkin

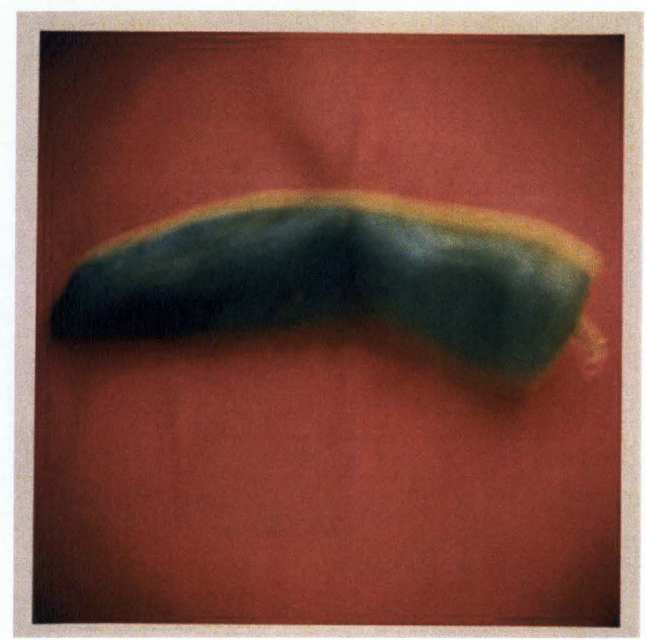

figure 7. Dan Larkin, Untitled, c. 1992 @ Dan Larkin

For some participants, like Weston Kemp, the choice of what they contributed was influenced by the intended audience. "I considered the primary audience, faculty colleagues, reviewed images that I had produced in the past year or so, and personally produced a limited edition of the selected image," recalled Kemp. ${ }^{39}$ Three of the four photographs he contributed were images of Stonehenge. It is a project that he has been working on for years and is reaching its culmination in an upcoming book. ${ }^{40}$ Howard LeVant contributed only to the 1988 portfolio, but his choice was also influenced by his

\footnotetext{
${ }^{38}$ Dan Larkin, email to the author, June 22, 2009.

${ }^{39}$ Weston Kemp, email to the author, July 11, 2009.

40 "Weston Kemp, Photographer, Professor, Writer," Weston Kemp, http://www.bentley-kemp.com/Weston/about_wes.html (accessed July 9, 2009).
} 
colleagues: "I chose images that did not reflect my commercial career, just to show the fine art types that I had a broader vision than they gave me credit for." ${ }^{\text {41 }}$ (See figure 8.)

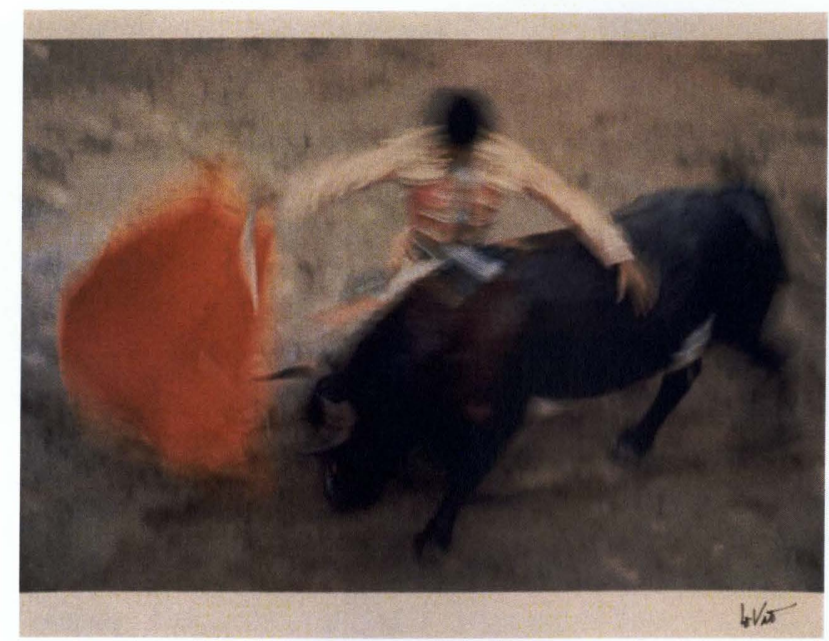

figure 8. Howard LeVant, Untitled, c. 1988

(C) Howard LeVant

Some participants' work seems very disparate from year to year but was always part of a project or series on which they were currently working. Willie Osterman does his work in series and said that "when an event arrives such as this I pick one and use it for the portfolio." ${ }^{42}$ The images he contributed to the portfolios are all black-and-white gelatin silver prints of subjects ranging from children playing in a creek to a nude figure (see figure 9 and 10). Denis Defibaugh said that his work in the portfolios "[was] almost always from series that I was working on." ${ }^{43}$ The fact that some participants contributed an assortment of unrelated subjects and processes while other participants contributed similar work year after year demonstrates differences in approach. Some participants used the portfolios to exhibit the evolution of a particular project on which they were

\footnotetext{
${ }^{41}$ Howard LeVant, email to the author, July 12, 2009.

${ }^{42}$ Willie Osterman, email to the author, May 11, 2009.

${ }^{43}$ Denis Defibaugh, email to the author, May 11, 2009.
} 
working over the years, while others' inclusions changed from year to year, as if the portfolios served as an announcement that they were still active photographically.

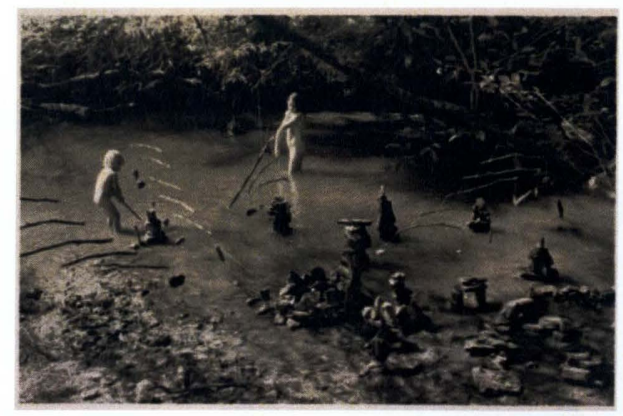

figure 9. Willie Osterman, Untitled, c. 1987 (C) Willie Osterman

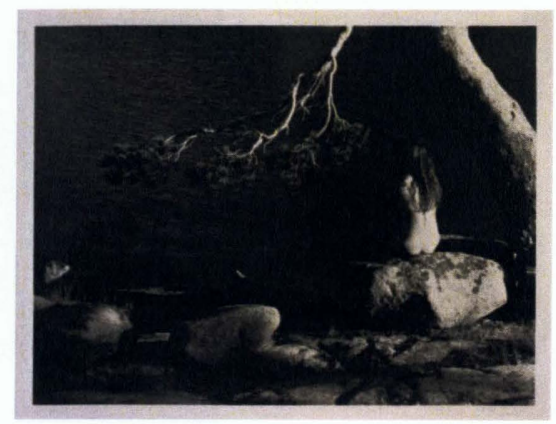

figure 10. Willie Osterman, Untitled, c. 1989 ㅇ Willie Osterman

In some cases, images included in the portfolios have been published on participants' websites; in other cases, submissions are unpublished parts of a series on which they were working. Jim Megargee's contribution to the portfolios was a part of his series "An American Tour," which he began in the early 1970s. J. Tomas Lopez recalled that the work he contributed was a part of a series he had been working on at the time of submission, of which some are now included in a permanent collection: "I am always working on a project. I believe the work I submitted in 1992 was part of my "Water Series" of which the Smithsonian Museum of American Art took three pieces for their collection that year." ${ }^{\prime 4}$ The contributions by Skip Battaglia are the most unusual in all the portfolios; most are drawings and mixed-media prints used as animation cells for films on which he was working at the time (see figure 11). Since each print was an individual cell, every portfolio contained a completely unique image, unlike the photographic

${ }^{44}$ J. Tomas Lopez, email to the author, May 20, 2009. 
contributions. Though the film and video program was still part of the SPAS at the time, contributions to the portfolios were restricted to prints due to physical constraints.

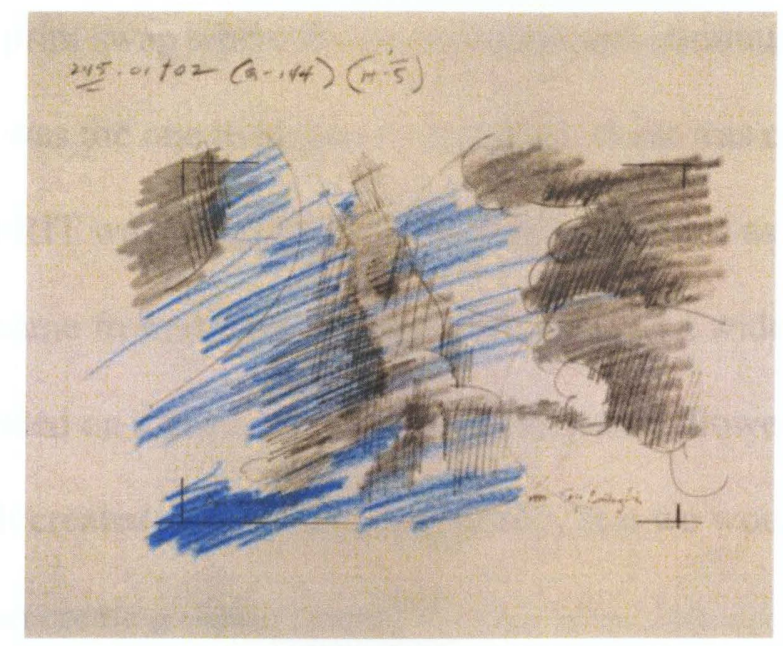

figure 11. Skip Battaglia, Untitled, 1989

(c) Skip Battaglia

Like any project involving a large group of people, some took it more seriously than others and approached it with a range of attitudes. One participant described the portfolios as "an ego trip for some, a serious desire to share work with co-workers on the part of some others." ${ }^{45}$ Participants' attitudes towards the portfolios can be seen from the types of photographs submitted as well as the processes by which they were produced. Michael Peres recalled some debate "between the fiber purist and the art world and then the RC [resin coated] black-and-white paper material [that] went through machines." ${ }^{, 46}$ Some participants were not happy that non-archival RC prints were being included with the finer quality fiber prints and silver dye bleach prints. Ultimately, though, the choice of materials used was up to each individual participant.

\footnotetext{
${ }^{45}$ Email to the author, July 12, 2009.

${ }^{46}$ Michael Peres, in discussion with the author, June 2, 2009.
} 
There was also some discussion as to whether the portfolios should be exclusive to faculty or if staff should be included. Peres described it as almost a philosophical discussion that he had in the halls with colleagues: "Are we trying to make a scholarly portfolio, or is this a print swap where the organization and community should participate?" ${ }^{, 47}$ Peres was the one to make the decisions; there was no committee. $\mathrm{He}$ noted that the staff at RIT was "incredibly resourceful and active as photographers" and, just like the faculty, came from diverse backgrounds and had a wide range of interests in photography. He decided on a principle of inclusiveness and allowed both faculty and staff to participate: "It created a sense, philosophically, that we would build bridges and community rather than create a class system." 48

Whether the portfolios created a sense of community is hard to measure. One participant said that "there was a sense of community in SPAS especially by the early 1990s," and that "the portfolio was just one type of camaraderie." ${ }^{49}$ Another participant stated that RIT "has always suffered from [a] lack of community." ${ }^{\text {50 }}$ In a sense, the staff and faculty were already brought together through photography simply by virtue of working in the field of photographic education. The portfolios were meant to transcend the barriers of the workplace; they connected everyone involved with photography through their "personal explorations" rather than the routines of a job or career. As objects, they were an attempt to embody a sense of community, but their compilation was handled primarily by Peres. Most participants remembered no social event or gathering to assemble the portfolios - only submitting prints to Peres and later retrieving an

\footnotetext{
${ }^{47}$ Michael Peres, in discussion with the author, June 2, 2009.

${ }^{48}$ Ibid.

${ }^{49}$ Email to the author, May 11, 2009.

${ }^{50}$ Email to the author, May 11, 2009.
} 
assembled copy of the portfolio. A few participants remembered an "unofficial" assembly session. "The only gathering I remember is when we would assemble them as a group. We would turn our prints in to Mike, and then have an assemble session at school," recalled Mark Sager. ${ }^{51}$ Peres remembered the final portfolio assembly session was like "dealing cards." ${ }^{, 52}$ Some of the participants, usually whoever was in the building, would volunteer to distribute the submitted prints and interleaving into the portfolio cases. This was an unofficial event that took place in a classroom at RIT, often only taking an hour to an hour and a half, done simply to assemble the portfolios without any kind of celebration.

The reason for contributing images to the portfolios varies among participants, but whatever the original use or purpose of the images, their placement in the portfolios decontextualized them. With the original context suppressed, the formal characteristics of the image were privileged and the image was aestheticisized, thus situating all of the images within a similar interpretive framework. Except for the cover page (which simply lists the participants in alphabetical order) and the brief inscription on many of the prints, no additional information on the images or their use outside the portfolios is provided. The portfolios were an egalitarian way to present, arrange, and store the personal work of the staff and faculty of the SPAS; all hierarchy that may have existed in the workplace was abolished. The images vary in size and process, but for the most part, the prints are all of uniform size and placement. Scientific images by Michael Peres are put on par with the portraits by Nancy Stuart and the scenes of Cape Cod by Dan Larkin.

\footnotetext{
${ }^{51}$ Mark Sager, email to the author, May 14, 2009.

${ }^{52}$ Michael Peres, in discussion with the author, June 2, 2009.
} 
The privileging of the image's aesthetics over its intellectual content is evident in the changes in Peres' own contributions. He spoke of the personal conflicts he had when he began teaching at RIT: "I'm a biomed photo guy, medical photography trained and a degree in biology. In my mind, all the technical and science work really was not that interesting outside of medicine and science to other people. ${ }^{, 53}$ After a friend of his saw some of his work in the faculty exhibition put on every year at RIT, Peres described a change in his perspective. The faculty exhibition mimics the portfolios in that they are both made up of eclectic work by the diverse group of photographers. Though Michael Peres said that he never contributed the same work to both the faculty exhibition and the portfolios, he described his first contributions to both of them as "what I thought was more expected or typical,"54 such as nature photography or landscapes. "One of my friends, who I had known for many years at the time, said, 'I can't believe you put pictures that are similar to everybody else ['s] in the photo faculty in the exhibition. Why don't you put in your microscopy? No one does microscopy; you'd be the only one. You're putting in what everyone else is.",55

Thereafter, Peres began to use his microscopy images in the faculty gallery show as well as the portfolios. "I didn't see myself as an artist. I saw myself as a technologist that worked with photography in medicine and science. So it was like a big push to be somewhere uncomfortable. Take science pictures and technical pictures and try to show them in galleries. So that was the impetus." ${ }^{, 56}$ The shift from what was "expected or typical" can be seen in the portfolios. In the 1987 edition, Peres contributed an image

\footnotetext{
${ }^{53}$ Michael Peres, in discussion with the author, June 2, 2009.

${ }^{54}$ Ibid.

${ }^{55}$ Ibid.

${ }^{56}$ Ibid.
} 
depicting an open window with vines outside of it (see figure 12). This is remarkably different from the microscopy that he submitted to later editions, such as Where Bone Meets Cartilage x 350 (see figure 13) in 1990. Like many other participants, Peres chose images from current projects that he thought "had the characteristics of interesting pictures whether it was shape or color or isolation or complexity. ${ }^{, 57}$ The images were not chosen by any level they operated on as scientific documents but through an aesthetic sensibility that made them "interesting pictures" in and of themselves, outside any other context.

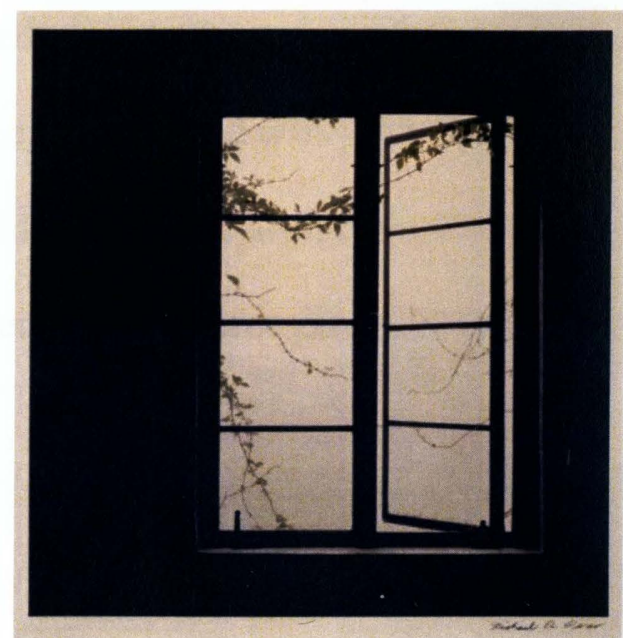

figure 12. Michael Peres, Untitled, c. 1987 (C) Michael Peres

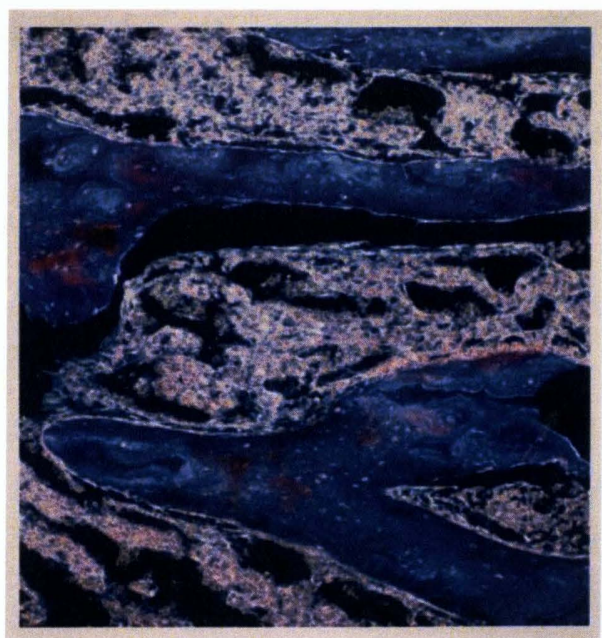

figure 13. Michael Peres, Where Bone Meets Cartilage $\times 350$, c. 1990 (C) Michael Peres

The participation and production of the portfolios had many tendencies similar to a camera club. Although some of the participants were only staff in the SPAS, while many of them were professionals who produced independent bodies of work outside that organization, they all had in common what Robert Castel and Dominique Schnapper

\footnotetext{
${ }^{57}$ Michael Peres, in discussion with the author, June 2, 2009.
} 
describe as a uniting factor in camera clubs: "not only their valorization of the photographic act, but, more particularly, their desire to take photographs in a different way." ${ }^{58}$ The faculty and staff had different levels of photographic ability, interest and proficiency, but participation in the portfolios connected them by an artistic pretension, whether participants believed the prints would be of interest only to other participants or to a broader audience. Photography's function in the portfolios is the same as its function in the camera clubs described by Castel and Schnapper: "Everything takes place as if it were rather the means of expression for an aspiration whose origin is not to be found within photography." ${ }^{, 59}$ Whether it's a faculty member who has been internationally exhibited, or a staff member who sees photography as a hobby, all participants chose the work they contributed with the idea of some level of artistic merit. Essentially, it was this shared idea of artistic aspiration, and the reduction of the images to their aesthetic characteristics, that brought the participants together.

\footnotetext{
${ }^{58}$ Robert Casal and Dominique Schnapper, "Aesthetic Ambitions and Social Aspirations: The Camera Club as a Secondary Group," in Photography: A Middle-brow Art by Pierre Bourdieu, translated by Shaun Whiteside (Stanford, CA: Stanford University Press, 1965), 104.

${ }^{59}$ Ibid.
} 


\section{Section II}

\section{$\underline{\text { Research Process }}$}

The six portfolios were hand delivered to George Eastman House on June 24, 2008 by Michael Peres. They were the personal copies of John Trauger, a Professor Emeritus in the School of Photographic Arts and Sciences who died in October 2007 at the age of 91 . His estate had donated the portfolios to RIT, but since there were already copies in the Library Special Collections, Michael Peres thought it would be better if the portfolios were given to George Eastman House because, in his words, they "would allow the work to be seen by a broader audience" 60

Jamie Allen, Assistant Curator at Eastman House, originally went through all six portfolios and checked the contents against each portfolio's cover page. The prints are not in alphabetical order, but most were signed on the front or back, which it made it easier to match the photographer to his or her prints. Some of the prints are unsigned, there are a few prints missing, and some of the signatures were illegible enough that they could be confirmed only through a complete examination of the portfolios' contents.

The project was passed on to me as an Institutional Service Opportunity (ISO), side projects on which students work while at the museum to gain experience outside of class. To be brought into the collection, the portfolios would have to go before the acquisition committee of the Department of Photographs, which requires an acquisition report to be written. First, though, the unattributed prints needed to be identified, and

${ }^{60}$ Michael Peres, email to the author, May 1, 2009. 
more information was needed on the portfolios, their production, and the participants involved. Jamie suggested that I first review each portfolio and then visit the RIT library, where she believed there were copies that might have better records.

I first went and looked at the portfolios donated to Eastman House. Since there was the possibility that RIT might have more information about their copies, I did not make a complete inventory of them as I did not want to duplicate already-existing work; I simply transcribed the signature on the prints (or made a note if it was unsigned), wrote a brief description of each image, and listed the order in which I found them in the portfolios. The 1987 portfolio has all 30 prints to match the 30 participants listed on the cover page, but two of them are unsigned: prints by Owen Butler and Richard Zakia. The 1988 portfolio has all 36 prints to match the 36 participants listed on the cover page but one is unsigned: the print by Patti Ambrogi. The 1989 portfolio list indicates that it contained 29 prints but was missing one by Patti Ambrogi. The 1990 portfolio cover page listed 29 participants but there are only 27 prints. There is also one unsigned, so three of the participants could not be immediately matched to prints: Owen Butler, Amy Friend and Keith McManus. The 1991 portfolio has all 23 prints to match the 23 participants listed, but there is one unsigned: the print by Michael Dear. The 1992 portfolio is supposed to contain 27 prints but there are two missing: one by Joan Boccino, and one by Loret (Falkner) Steinberg.

Some of the signatures are easier to decipher than others. The more I worked with the portfolios the more familiar the signatures became, but there were several that remained illegible. This was further complicated by the fact that there are several missing prints whose authorship I could not at first ascertain. Throughout the process I continued 
to revise several of the matches. I also discovered that none of the six portfolios donated to Eastman House are in alphabetical order; in fact, they seem to have no order at all.

I contacted Judy Sidlauskas at the Special Collections in Wallace Library at RIT and made an appointment to look at their copies. To my disappointment, I discovered that they are barely cataloged at all. There are also two extra editions of portfolios that came after the 1992 edition that are not included with the six donated to Eastman House. One is from May 1993, while another is dated May 1997 with "1995-1996 collection" in parentheses. These extra two give the archives at RIT a total of eight. They are simply listed by the call number TR654.S353 and volume 1-9, with each volume being a different portfolio. There is no volume 8, but I presumed that it would be from 1994 since volume 7 is from 1993 and volume 9 is from 1997 (1995-1996). I also discovered that volume 4 and volume 5 are both copies of the 1990 portfolio, and there is no copy of the 1991 portfolio. This is contrary to the library records of the portfolios that list volume 4 as “(1990) 25 photographs, 2 drawings" and volume 5 as "(1991) 25 photographs, 2 colored drawings.

While looking through the copies at RIT's Special Collections, I compared my brief inventory to theirs. The 1987 portfolio at both Eastman House and RIT has 30 prints, and the same two images are unsigned. The 1988 portfolio has 36 prints, just like the copy donated to the Eastman House. In the copy at RIT, the photograph by Patti Ambrogi was signed. I noticed the reverse with the photograph by Duane Hansen: the RIT copy is signed while the Eastman House copy bears Hansen's signature. The RIT

${ }^{61}$ Rochester Institute of Technology Wallace Memorial Library, "School of Photographic Arts and Sciences faculty/staff portfolio," Rochester Institute of Technology, http://albert.rit.edu/record=b1067929 S3 (accessed June 23, 2009). 
copy of the 1989 portfolio has all 29 prints to match the 29 participants listed, unlike the one donated to Eastman House, which was missing one by Patti Ambrogi.

One of the RIT copies of the 1990 portfolio was the most revealing; inside there is a sticky note with the handwritten message "2 'Xed' photos were never contributed to the project - consider this complete as is." On the introductory page there is an " $\mathrm{X}$ " by the names Keith McManus and Doug Rea. The same print that was unsigned in the Eastman House copy was also unsigned in this RIT copy. There were three matches that I was unsure about, but the "X"'s rule out Keith McManus and Doug Rea for the unsigned print, so I was able to conclude that it was made by Amy Friend. The other copy of the 1990 portfolio did not have a sticky note or "X"'s by McManus and Rea on the introductory page. It was also missing two prints and the same print was unsigned. The RIT copy of the 1992 portfolio is also missing two of the 27 prints that are suppose to be in it. There are "X"'s next to the names of Joan Boccino and Loret Gnivecki Falkner (Steinberg).

Another thing I noticed about the portfolios was the order of the prints. Just like the copies at Eastman House, none of the prints are in alphabetical order by name of photographer. One of the RIT copies of the 1990 portfolio is in the same order as the 1990 portfolio at the Eastman House, while the other 1990 copy at RIT is in the same order except for the first print. The RIT copies of the 1987, 1988, 1989 and 1992 portfolios have many sections that are in the same order as sections of their Eastman House counterparts. This led me to believe that although there seems to be no order in the copies of the portfolios at the Eastman House, the order is not totally random since the RIT copies have the same or slightly altered order. From my later discussion with 
Michael Peres, I concluded that the order of the prints comes from either the order they were submitted to Peres or the order in which they were put in the portfolios while being assembled.

Although I was disappointed at the state of RIT's records of their copies of the portfolios, it did assign names to some of the missing and unsigned prints. The next step was to make an inventory of the portfolios. This included taking a reference image and recording the following information about each print: photographer; date or date printed; medium; image dimensions; overall dimension; title (whether it was on the object, descriptive, or published); recto inscription; and verso inscription. I then put all the information into an Excel spreadsheet, which helped me analyze and manage the contents of the six portfolios. The inventory is needed for the acquisition report in order that the acquisition committee has a better idea of the portfolios' contents. Several of the categories (e.g. image dimensions, recto inscription, verso inscription) are not needed for an acquisition report, but they were useful for my own research on the portfolios and will hopefully facilitate the process of fully cataloging the contents into The Museum System (TMS), the Eastman House's collections management system. I noted in the spreadsheet any information about which I was unsure or that was missing. For example, there were several prints whose processes I was unable to determine (e.g. chromogenic versus silver dye-bleach process, etc.), as well as several prints that looked like an early digital output process (certain prints contributed by Doug Rea, Owen Butler and Loret [Falkner] Steinberg).

My next step was to do further research on the participants and their projects. I began by making a list of every photographer that was involved with the six portfolios 
and then looked up their names in TMS at Eastman House. I discovered that several photographers (Charles Arnold, Jr, Guenther Cartwright, Judy Natal, Elaine O’Neil, John Retallack, and Nancy M. Stuart) already have work in the Eastman House collection. I compiled biographical and contact information I could find about each participant. Many of them still work for RIT or in the photography industry, so it was relatively easy to find information on them through their personal websites or RIT's website. I also found information through books they had published and files at the Robert and Ronay Merschel Library at Eastman House. I looked at telephone directories, course catalogs and schedules from the years the six portfolios were produced. This was especially useful in finding information about participants who had been members of the staff or who had worked for RIT for a short time. However, there remained a few for whom I could find little or no information or means of contact.

I began to email all accessible participants, asking about their memories of the project: if they made work specifically for the portfolio or if it came from personal workin-progress; whether there was some kind of event to assemble the portfolios; memories they had about RIT at the time; and biographical information.

Bob Kayser, a retired professor from RIT, was gracious enough to invite me to come to his house in Brighton, New York to look at his copies of the portfolios. This was useful because I was able to look at another participant's copies in addition to Trauger's. I was able to confirm that there were nine editions of the portfolio made. Trauger did not participate in the last three, so he did not have copies of those. Kayser had all nine, and he had labeled them by year. Unlike the other two copies I had seen, the prints were all in alphabetical order by photographer. Because they were in order, and through my 
discussion with Kayser, I was able to determine the authors of all unsigned prints. I was also able to confirm that the missing prints in the 1990 and 1992 editions were never contributed. Kayser told me that the list of participants on the cover page was printed before the contributions were submitted or the portfolio assembled. In the 1990 portfolio, Keith McManus and Doug Rea failed to contribute prints, and the same happened with Joan Boccino and Loret (Falkner) Steinberg in the 1992 portfolio. However, Kayser actually obtained a photograph by Loret (Falkner) Steinberg for the 1992 portfolio that was received after the portfolios had been assembled.

Kayser was also instrumental in helping me work through some of the questions I had on specific photographic processes in the portfolios. There are several photographs that look like silver dye bleach prints, but the paper was manufactured by Kodak, a company not known for the production of this kind of photographic material. Many of Kayser's photographs had this appearance and he was able to tell me that the Kodak paper prints were actually Type R prints, or reversal prints, a chromogenic process.

I still had several questions on some of the other processes in the portfolios, so I met with Taina Meller from the Conservation Department at Eastman House. She helped confirm which were silver dye bleach and which were chromogenic. Although we did not confirm all the processes for the digital prints, we were able to identify a few from looking at them under the microscope and comparing them to printer paper samples. For example, the print Loret (Falkner) Steinberg contributed to the 1990 portfolio is most likely a thermal autochrome, while the print Russ Lunn contributed to the 1988 portfolio was most likely a thermal print made with a copy machine. 
She also gave recommendations on the storage of the portfolios as a whole. She thought that the photographs in the portfolios were in physically good condition and recommended that the prints continue to be stored in the same manner they are now, if not more consistently. This involves keeping the Light Impressions Renaissance paper between each print stacked on top of one another and removing any extra material in which the prints may be currently stored (e.g. one of the prints is kept in folded glassine while a few others are kept in acetate envelopes).

Now that I had a complete inventory of the portfolios, I wanted to find out more about their actual production. I had previously corresponded with Michael Peres through email, but on the urging of Bill Kayser, I scheduled a time to interview him. Peres was very helpful and willing to discuss all of my questions. Although production had begun over twenty years ago, he was able to provide details about the portfolios that aided greatly in my research, including information about how they were assembled, why both faculty and staff were included, why some prints were missing, and why production of them eventually ended.

With all the information I had gathered on the portfolios, I was ready to write the acquisition report. To do this I looked at acquisition reports put together for previous acquisition committee meetings and relied on the thesis of Allan David Phoenix, which describes the purpose of an acquisition report and its components. With this as a basis, I wrote an acquisition report that physically and intellectually describes the six portfolios, how they relate to Eastman House, and recommends them for acquisition. The acquisition report also includes the inventory I made of the portfolios and a brief biography of each participant. 


\section{Further Research}

The six portfolios encompass 169 prints and 52 individual participants. Although many of the participants are still alive, finding contact information was more difficult than I first imagined. As a result, some of the biographies in Appendix A remain incomplete. Additional information on some of the participants would provide a better understanding of the portfolios and their contents.

Participants I was able to contact were very helpful in their responses, but as the first edition was produced twenty-two years ago, many participants had a hard time recalling certain details or had conflicting memories. Even Michael Peres, the director and organizer of the project, sometimes had trouble remembering different aspects of the production of the portfolios. More complete interviews with the 52 participants would give further insight on why individuals chose to contribute certain images, why some chose not to participate in some of the portfolios, and individual participants' attitudes toward the project. There are also several questions I was unable to answer, such as why the Patti Amborgi print in the 1989 portfolio was missing in John Trauger's copies of the portfolios but was found in Bob Kayser's portfolios and the copy at the RIT Library; why there were two copies of the 1990 portfolio at the RIT Library but no copies of the 1991 edition; and what happened to the copies of the portfolios in the Office of the Dean of the College of Imaging Arts and Sciences.

With a total of 169 disparate prints in the portfolios, there is always room for more research. While I have discussed some of the individual prints, the information known about the majority comes only from what is inscribed on their backs or fronts. 
Further research on the prints, which would involve additional correspondence with individual participants, would provide Eastman House with a better insight and understanding of these objects and could increase their value to the collection. 


\section{Section III}

\section{Importance of an Acquisition Report}

Acquisitions are the blood of an institution. A living institution may acquire new objects for its collection to build upon weaknesses or fill holes in the collection. It may also do so to complement or emphasize objects already in the collection. Non-purchased acquisitions may be made by donation, bequest, or conversion (i.e. objects on loan unclaimed by the owners). ${ }^{62}$ The six portfolios under consideration for acquisition are donations from RIT.

Before an object can be accessioned into the permanent collection it must be acquired. An acquisition is made when the title of an object is transferred to the museum. An accessioned object is something that has been acquired by the museum and recorded/processed into the permanent collection. ${ }^{63}$

At Eastman House, before an object may be acquired for the collection, the curator must first propose the acquisition of that object before the acquisition committee. Each department has it own acquisition committee (in this case it is for the Department of Photographs) made up of members appointed by the Board of Trustees. Members of the acquisition committee are made up of both Trustees and non-Trustees, but they must all understand the mission of Eastman House and its collection policy. After reviewing the object presented by the curator, the acquisition committee votes to approve or deny

\footnotetext{
${ }^{62}$ Rebecca A. Buck and Jean Allman Gilmore, eds. The New Museum Registration Methods (Washington DC: American Association of Museums, 1998), 157. ${ }^{63}$ Ibid.
} 
acquisition. Based on the decision made by the members of the acquisition committee, the chairperson of the acquisition committee makes the recommendation (of approving or denying acquisition) to the Board of Trustees. The Board of Trustees then votes on whether to ratify this recommendation, with ratification finalizing the decision.

An acquisition report serves as a guide for members of the acquisition committee to review objects under consideration for acquisition. In Allan Phoenix's thesis "Preparing An Acquisition Report for The Portfolio, F. Frith's Photo-Pictures of the Lands of the Bible Illustrated by Scripture Words" he describes an acquisition report as a means by which an acquisition committee can "assess how an object on approval will add value to the collection and to decide whether or not to purchase, or, in case of a donation, to accept a work into the collection." ${ }^{64}$ He goes on to say that it is "also an affirmation of the knowledge, taste, and decision of the curatorial section of the departments." ${ }^{, 65}$

Since the portfolios are part of a set, I have decided to create one acquisition report for all six of them. Based on previous acquisition reports at Eastman House and Allan Phoenix's previously mentioned thesis, I have divided the acquisition report into sections. As Allan Phoenix's acquisition report was also made for Eastman House, I have closely followed his model to continue the precedent that he has set. The acquisition report is divided into physical description, condition, biographies, dates, titles, provenance, and relationship to the collection. ${ }^{66}$ This report will be the official document

\footnotetext{
${ }^{64}$ Allan David Phoenix, "Preparing An Acquisition Report for The Portfolio, F. Frith's Photo-Pictures of the Lands of the Bible Illustrated by Scripture Words" (master's thesis, Ryerson University, 2008), 10.

${ }^{65}$ Ibid., 12.

${ }^{66}$ See Allan David Phoenix's thesis "Preparing An Acquisition Report for The Portfolio, F. Frith's Photo-Pictures of the Lands of the Bible Illustrated by Scripture Words" for a more complete explanation of each component.
} 
presented to the acquisition committee and will contain all information necessary for them to make an informed judgment about the portfolios.

Due to the number of photographers involved, the biographies have been listed in Appendix A following the acquisition report; an inventory of all six portfolios (which includes attribution, medium, title, and date) is included in Appendix B. Although part of the appendices, the sections of biographies, dates and titles, are briefly mentioned in the acquisition report. 


\section{Acquisition Report}

\section{Six Portfolios from the Faculty and Staff of the School of Photographic Arts and Sciences at Rochester Institute of Technology, May 1987 - May 1992}

\section{Gift of Rochester Institute of Technology; coordinated by Michael Peres.}

\section{Physical Description}

There are six portfolios consisting of a total of 169 prints made by various photographic processes. Each portfolio box opens like a clamshell and measures roughly 15 ” x 12" (38 x $30 \mathrm{~cm}$ ) when closed. They are archival-quality boxes made of black heavyweight binder board and lined with white paper inside. There is no writing on any of the outside or inside of the portfolio boxes. At the front of each portfolio is a hand-printed cover page on high-quality paper. The text changes slightly for each portfolio but begins by stating the date the portfolio was compiled, the edition, the number of participants involved, two brief paragraphs on how and why the portfolio was produced, and an alphabetical list of the participants.

Except for some minor differences, the text for the cover page for the 1988 edition is used as a basis for the text for the cover page in the following editions. It states, "This body of work is a self directed project consisting of photographs which [sic] represent personal areas of exploration by each of the photographers." It continues with "There is no theme to this portfolio or reason for it's [sic] origin other than to share work amongst the participants." 
Each portfolio has a different number of prints. Each participant involved submitted only one print, and three of the portfolios have fewer prints than participants listed on the cover page. The following list states the number of participants listed and the number of prints actually found within:

- $1987-30$ participants are listed and it contains 30 prints

- 1988 - 36 participants are listed and it contains 36 prints.

- $1989-29$ participants are listed but it only contains 28 prints

- 1990 - 29 participants are listed but it only contains 27 prints

- 1991 - 23 participants are listed and it contains 23 prints

- $1992-27$ participants are listed but it only contains 25 prints

'The 1989 portfolio is missing a photograph by Patti Ambrogi. This photograph was found in other copies of the portfolios and it is not clear why it is missing from the Eastman House copies. The 1990 and 1992 portfolios each have two fewer prints than participants listed (i.e. Keith McManus and Doug Rea in the 1990 portfolio; Joan Boccino and Loret [Falkner] Steinberg in the 1992 portfolio). Comparisons to other copies of the portfolios show that these participants' prints were never included in those editions. The cover pages that list the participants for each of the portfolios were made before the prints were compiled. Those participants that are listed but did not contribute chose not to do so after the cover page had already been printed. Since the cover pages were hand-printed, it was too expensive to re-print them.

The 169 photographs are all roughly 11 " x 14 " $(27.94 \times 35.56 \mathrm{~cm})$ and are stacked loosely on top of one another inside the portfolio boxes. Interleaving sheets made from non-buffered Light Impressions Renaissance paper are placed between each print. 
Most of the prints have an inscription on the front or back. A wide range of photographic processes (e.g. chromogenic prints, silver dye bleach prints, gelatin silver prints) and genres of photography (e.g. nature, portraiture, photojournalism, scientific, fine art, etc.) is represented within the portfolios (see Appendix B for a complete detailed inventory of each portfolio).

It must be noted that there was a total of nine editions made in this series. The editions from the years 1993, 1994, and 1997 (collected from 1995-1996) are missing from this set. Eastman House also already has four portfolios from RIT already in the collection. These are from the years 1973, 1975, 1978, and 1979. They were assembled by the students and faculty in the MFA program and are not related to the six portfolios under consideration.

\section{Condition}

All six portfolios are in good condition. There are several scratches, scrapes and blemishes on the boxes, but none are serious enough to warrant attention. The photographs within are in good condition and there are no major handling issues. There are a few minor color shifts in some of the chromogenic prints and a few gelatin silver prints have minor deterioration, but these are most likely intrinsic and do not merit any treatment or extra precautions. The contents of all six portfolios can be stored as they are now in the portfolio cases with the same interleaving currently in use. A few of the prints are encased in extra protective material, such as acetate or glassine (these are noted in Appendix B), but it is recommended that this extra material be removed. 


\section{Biographical Information}

There are a total of 52 participants involved in all six portfolios. All were members of the faculty or staff with the School of Photographic Arts and Sciences at Rochester Institute of Technology at sometime between May 1987 and May 1992. For most of the prints, authorship was determined by signature inscription. A few of the prints were without any signature and their authorship was determined by comparisons to other copies of the portfolios or correspondence with participants. A brief biography of each participant, along with a list of the portfolios in which he or she has prints, is listed in Appendix A. The prints without signatures are noted in Appendix B.

\section{Titles}

The title of each portfolio is simply Rochester Institute of Technology School of Photographic Arts and Sciences Faculty and Staff Portfolio, followed by the date of the portfolio (for example, Rochester Institute of Technology School of Photographic Arts and Sciences Faculty and Staff Portfolio, May 1987 or RIT SPAS Faculty and Staff Portfolio, May 1987). Titles associated with individual prints were taken from inscriptions or given a brief descriptive title if there was no inscription. A few of the prints have published titles (see Appendix B).

\section{Dates}

The portfolios were assembled each May from 1987 to 1992. The prints within have individual dates associated with them. They were either taken from inscriptions on the prints or given a circa date from the date of the portfolio in which it was found. On 
several of the prints there were two dates found; the earliest one is understood to be when the negative was made and the later one is when the print was made. See Appendix B for a full inventory of all six portfolios.

\section{Provenance}

All six of the portfolios originally belonged to John Trauger, a Professor Emeritus in the School of Photographic Arts and Sciences who died in October 2007. His estate donated the portfolios to RIT, but RIT made the decision to donate them to Eastman House because they already had copies of them in their Special Collections.

\section{Relationship to the Collection}

The six portfolios represent a wide range of photography originating from a variety of photographers who had, at one point, been a part of photographic education at Rochester Institute of Technology. Many of the participants are still faculty or staff at RIT; some left for other endeavors or have since retired; while several others were involved with RIT for only a brief time. While some of the photographers are not well-known figures in the industry, others are prominent and renowned in their field. The portfolios not only contain personal work by individual photographers, they offer a sample of some of the many photographic disciplines present within that institution at that time and their practical application.

The participants Charles Arnold, Skip Battaglia, Owen Butler, Guenther Cartwright, Judy Natal, Elaine O’Neil, John W. Retallack and Nancy Stuart already have work in the collection, and their work in the portfolios would simply expand this 
presence. There are a multitude of connections between Eastman House and RIT, with many participants having direct involvement with Eastman House apart from work in the collection. Charles Arnold was an assistant to Beaumont Newhall at Eastman House from 1954 to 1956 before teaching at RIT. Owen Butler and Elaine O’Neil both had solo shows here; while Patti Ambrogi, Guenther Cartwright, Dan Larkin, Judy Levy, Judy Natal, and Elaine O'Neil have all been included in group shows. Several of the participants also had major involvement with the $4^{\text {th }}$ Edition of the Focal Encyclopedia of Photography, which was compiled in collaboration with Eastman House. Michael Peres, the organizer of the portfolios, was Editor-in-Chief, while Nancy M. Stuart and J. Tomas Lopez were section editors along with Grant Romer and Mark Osterman from Eastman House. Many other participants contributed individual chapters.

The majority of the participants in these portfolios are not currently represented in the Eastman House collection. The addition of the portfolios to the collection would fill holes left by an absence of several photographers who have been active regionally, nationally or internationally, such as Lynne Bentley-Kemp, Ira Current, Andrew Davidhazy, Denis Defibaugh, J. Tomas Lopez, Willie Osterman, and Richard Zakia, among others.

Besides containing representative work by a variety of individual photographers, whether already in the collection or not, the portfolios as a whole can be seen as a compilation of some of the many practical applications of the photographic medium, many of which were actively being taught at RIT at the time. The portfolios would add images to the collection that are often underrepresented or overlooked in the history of photography, such as the scientific images by Michael Peres, Amy Friend, and William 
Fischer; the electrostatic prints by Charles Arnold; or the distorted images that Andrew Davidhazy produced using his custom-made cameras. In the late 1980s and early 1990s, the School of Photographic Arts and Sciences contained many programs representing a variety of photographic disciplines, hence the many types of photographs represented. The participants come from diverse backgrounds and demonstrate a wide range of photographic education, experience and interest. The portfolios stand as an artifact from a certain period in the history of photography - a time capsule of the activities of the faculty and staff in the School of Photographic Arts and Sciences at RIT, a school renowned for its photographic education. Not only do they show the personal photographic interests among a diverse group of people, but those of a group working in the field of photographic education who were teaching future photographers. The many processes within, from gelatin silver prints to Cibachrome to early thermal printing, make the portfolios an important catalogue of that moment in the history of photographic technology; they document the roots of the digital era, and many processes common at that time, some which are unavailable today. The early thermal printing processes even anticipated the changes in photography and photographic education that were just on the horizon at the time. As photography becomes increasingly digital in nature, the historic value of the portfolios will increase as many of the processes they contain become obsolete.

The portfolios were assembled to consolidate and celebrate the community of the staff and faculty in the SPAS; the prints they contain represent "personal areas of exploration by each of the photographers" with their raison d'être to "share work amongst the participants." Though the participants' workplace was the common ground, the 
portfolios offered a chance to connect personally and artistically apart from the workplace, using the very skill that brought them together. Whether the portfolios were successful in accomplishing this goal can be determined only by those who participated, but they remain a testament to the possibilities of photography as a social unifier, a theme present in photography since its inception.

The six portfolios make a fine addition to the collection of Eastman House and they are recommended for acquisition. Although the images will certainly have more meaning to the individuals who participated, they also have value to Eastman House on other levels. Additional information and research is encouraged for individual participants and prints, but besides adding the work by individual photographers, the portfolios play a part in the history of photography. RIT and Eastman House are both renowned institutions that serve not only the same community but are highly regarded internationally. The mission of Eastman House is to tell the story of the history of photography; Rochester Institute of Technology has added to this history through its contribution to and development of photographic education - an under-represented subject in the history of photography. The portfolios are relevant to that history due to the participants' involvement with photographic education at that institution. Some of the participants are lesser-known photographers, some more widely known, while many pursued photography simply as a hobby; the history of photography encompasses all of these levels of engagement with the medium. The portfolios, as a whole, provide a means for scholarly research on where photography has been, where it is going, and the personal interest and aspirations of its individual participants. 


\section{Appendix A}

Biographies of Participants in the Rochester Institute of Technology

School of Photographic Arts and Sciences Faculty and Staff Portfolios,

\section{$\underline{1987-1992}$}

The following is a compendium of brief biographies about each of the individual participants in the six portfolios. Information for these biographies was drawn from correspondence with the participants, websites, books, course catalogs and telephone directories. Some individuals have biographies and updated information readily available while others have slipped through the cracks and little information could be found. As a result, biographical information varies in length. Sources for the biographies are listed below each individual entry to facilitate referencing. The editions of the portfolio in which each individual has prints are listed in parentheses by each individual's name.

\section{Patti Ambrogi (1988)}

American (b. 1950)

Patti Ambrogi was born in Albany, New York. She earned a BA from Albany State and an MFA from Visual Studies Workshop in 1976. She is presently an Associate Professor of Photography at RIT. She created and developed the Media Café where students produce time-based work that explores media's continuous shifts in interpretation. Her work often deals with issues such as female identity, movement, censorship, and the influence of media. In 1989, four anonymous complaints were brought against Ambrogi for child abuse and pornography. These charges revolved around her photographs depicting her twin daughters nude. While these accusations were found to be without merit, the event influenced Ambrogi to address censorship in her art while an artist in residence at Lightwork in Syracuse. Her videos have been shown at conferences for the Society of Photographic Education, Visual Communications, and the International 
Conference on the Arts and Humanities. She is a recipient of the Eisenhart Award for Outstanding Teaching along with many grants and awards.

\section{Sources:}

The Media Cafe, "Patti Ambrogi," Rochester Institute of Technology, "http://mediacafe.rit.edu/about.html (accessed July 8, 2009).

Photographic Resource Center, "Syntax," Boston University, http://www.bu.edu/prc/syntax.htm (accessed July 8, 2009).

Michael Leonard, "Patti Ambrogi," Visual Studies Workshop, http://vswmovement.org/artist.php?artist=ambrogi (accessed July 8, 2009).

\section{Charles Arnold (1987, 1988)}

American (b. 1922)

Charles Arnold was born in Providence, Rhode Island. He joined the US Navy during WWII and then received a BFA in Illustration from the Rhode Island School of Design (RISD) in 1949. For five years he worked as a museum photographer at RISD and taught the first photography elective there in 1953. In 1954, he went to Eastman House where he met Minor White and Beaumont Newhall. Newhall offered him the job of curatorial assistant at which he worked until 1956. From 1955 to 1960, he was also a designer and design consultant for Aperture magazine. While at Eastman House, he taught a photographic workshop attended by Ralph Hattersley and Neil Croom, teachers in the photography program at RIT. Through them he met C.B. Neblette, who hired him to teach photography at RIT in 1956. Along with Minor White, Ralph Hattersley and Neil Croom, he was instrumental in developing the BFA in photography program and served as its first chairman for seven years. Along with Arnold Sorvari, he helped develop the MFA program in photography. In 1964, he began the serious exploration of electrostatic imaging processes (Xerography) that he became most known for. In 1966, he received an MFA in Communications Design from RIT. In 1970 to 1971, as part of a teaching exchange, he taught at the London Polytechnic School of Photography. In 1975, he spent five weeks in Sao Paulo, Brazil as photographic consultant to Editora Abril (South America's largest publisher at the time). He returned to Brazil in 1977 with a FulbrightHayes Senior Lectureship to exhibit and lecture. He has exhibited in group and solo shows in Brazil, Canada, England, Finland, the Netherlands, and the United States. He retired from RIT in 1987 and still exhibits his work.

\section{Sources:}

Nancy M. Stuart, "The History of Photographic Education in Rochester, New York, 1960-1980" (PhD diss., State University of New York at Buffalo, 2005).

The Museum System, George Eastman House Collections Management System (accessed July 9, 2009). 


\section{Jodi Baker (1992)}

American

Jodi Baker was a Facilities Coordinator in the School of Photographic Arts and Sciences. She started at RIT around 1989 and left around 1995.

Sources:

Michael Peres, in discussion with the author, June 2, 2009.

Greg Barnett $(1987,1988)$

American

Greg Barnett is the Director of Operations in the Office of the Dean of the College of Imaging Arts and Sciences.

Sources:

Greg Barnett, email to the author, May 14, 2009.

Skip Battaglia $(1988,1989,1990,1991,1992)$

American (b. 1948)

Skip Battaglia received a BA in English and Philosophy from Boston College in 1970 and an MS in Television-Radio from Syracuse University in 1974. He was a high school English teacher at St. Joseph's Collegiate Institute in Buffalo, NY from 1971 to1973; adjunct faculty in the Department of Fine Arts at the University of Rochester from 1977 to1981; and an Associate Professor in the Department of Communications/Journalism at St. John Fisher College from 1981 to 1987 . He joined the faculty at RIT in 1987 and became a full professor in 1997. He is currently a professor in the School of Film and Animation at RIT where he teaches graduate and undergraduate students film production, animation, scriptwriting, and aesthetics courses. He is a member of the Association of Independent Video and Filmmakers, American Society of Independent Film Animators, and the Fulbright Association. In 1992, he received a grant from the New York Foundation of the Arts towards professional development and arts experimentation. He is the creator of many award-winning films, including Crossing the Stream (2006), Second Nature (2000), More True Shit (2003), I would Always Slow Down (2001), Taki Dom (1997), Restlessness (1994) and Geologic Time (1989). His films have screened internationally and are in many collections around the world, including the Museum of Modern Art; George Eastman House; British Film Institute, London; D.W. Griffith Cineteca, Genoa Italy; International Animation Library, Tokyo; as well as institutions in Bulgaria, Australia, Spain, New Zealand, China, Croatia and Serbia. 
Sources:

Skip Battaglia, "Skip Battaglia," Rochester Institute of Technology, http://people.rit.edu/cfbpph/main.html (accessed July $8^{\text {th }}, 2009$ ).

Lynne Bentley-Kemp (1988, 1989, 1990, 1991, 1992)

American

Lynne Bentley-Kemp grew up in Westbury, New York. She attended RIT where she received a BFA in 1974 and an MFA in Printmaking in 1978. In 1973, she married Professor Weston Kemp. She was a tenured professor at RIT where she taught courses in art, gallery management, and photography to undergraduate and graduate students. She also was a photography instructor for hearing impaired students. From 1996 to 1999, she served as Chair of the Fine Art Photography Program. In 2003, Bentley-Kemp received her $\mathrm{PhD}$ in Comparative Studies from Florida Atlantic University. Her dissertation, "Recovering Eden: The Photographer in the Garden," analyzed the work of six photographers and their relationship with American landscape. She is currently a resident of Cudjoe Florida and head of the photography program at Florida Keys Community College. She continues to work as a fine art photographer with a variety of processes, including infrared, non-silver, and digital techniques. Her work is exhibited nationally and held in many private and public collections. She wrote the section "Photography Programs in the $20^{\text {th }}$ Century Museums, Galleries, and Collections" for the fourth edition of The Focal Encyclopedia of Photography.

\section{Sources:}

Nancy M. Stuart, “The History of Photographic Education in Rochester, New York, 1960-1980" (PhD diss., State University of New York at Buffalo, 2005).

Michael R. Peres, ed. The Focal Encyclopedia of Photography: Digital Imaging, Theory and Applications, History and Science, $4^{\text {th }}$ ed. (New York: Focal, 2007).

Lynne Bentley-Kemp, "Lynne Bentley-Kemp PhD: Artist Professor, Scholar," BentleyKemp, http://www.bentley-kemp.com/Lynne/about.html (accessed July 8, 2009).

\section{Joan Boccino $(1990,1991)$}

\section{American}

Joan Boccino is a filmmaker and was part of the faculty in the Film and Video Program in the School of Photographic Arts and Sciences.

Sources:

Michael Peres, in discussion with the author, June 2, 2009. 


\section{Owen Butler (1987, 1988, 1989, 1990, 1991)}

American (b. 1938)

Owen Butler attended RIT from 1956 to 1958. In 1968, after years working as a photographer in New York City, he returned to RIT to finish his BFA. He studied at RIT with Minor White and Ralph Hattersley and became friends with such renowned photographers as André Kertesz and W. Eugene Smith. He served as Chair of the Applied Photography Program at RIT for four years and Co-Chair of the Military Photojournalism Program for eight years. He has taught large-format photography, underwater photography, photographic communications, commercial photography and fine art studio photography. He has embraced digital technology and founded OB Press, which prints digitally designed and printed books. Since 1968, Butler has participated in over 40 group and solo shows at such places as George Eastman House, the Indiana University Museum, the Pratt Institute, Museum of Modern Art and the Museum of Image and Sound in Brazil. He has publication credits in Advanced Black-and-White Photography; the fourth edition of The Focal Encyclopedia of Photography; Less Than Sharp; and Photography for Visual Communicators. He is on the advisory board of Photographer's Forum Magazine and has consulted for Eastman Kodak Company and Serbin Communications. RIT announced the Owen Butler Photography Scholarship in 2004, which is funded by a former student to honor Butler.

\section{Sources:}

Nancy M. Stuart, "The History of Photographic Education in Rochester, New York, 1960-1980" (PhD diss., State University of New York at Buffalo, 2005).

Michael R. Peres, ed. The Focal Encyclopedia of Photography: Digital Imaging, Theory and Applications, History and Science, $4^{\text {th }}$ ed. (New York: Focal, 2007).

Beyond Second, “Topic: Owen Butler Lecture," Harrisburg Area Community College, http://www.beyondsecond.com/forum/?topic=47 (accessed July 8, 2009).

\section{Guenther Cartwright (1987, 1988, 1989, 1992)}

American (b. Germany, 1945)

Guenther Cartwright was born in Reichenberg, Germany. After receiving his undergraduate degree in 1968, he took a few evening photography courses and became a manager at the photo facilities of Moore College of Art in Philadelphia. He began teaching in the degree program not long after. He received an MFA from Visual Studies Workshop in 1975. In 1977, he joined the staff at RIT where he taught photojournalism and applied photography. He has exhibited nationally and internationally in both solo and group shows, including the Smithsonian Institute; George Eastman House; the National Museum of Photography, Bradford, England; The Photographers' Gallery, London; and 
Photokina, Köln, Germany. He has been a recipient of a Polaroid Corporation Photographers Grant and a New York State Council on the Arts Public Service Grant. He wrote the section "Photojournalism" in the fourth edition of The Focal Encyclopedia of Photography. He retired from RIT at the end of the 2007-2008 academic year.

\title{
Sources:
}

Nancy M. Stuart, "The History of Photographic Education in Rochester, New York, 1960-1980" (PhD diss., State University of New York at Buffalo, 2005).

"SPAS Faculty On Line: Guenther Cartwright," Rochester Institute of Technology, http://www.rit.edu/cias/ritphoto/faculty-work/pages/cartwright-1.html (accessed July 9, 2009).

\section{Kathleen Collins (1987, 1989)}

\author{
American (b. 1945)
}

Kathleen Collins was born in Chicago. She received a BA in Psychology from Stanford in 1967 and an MFA in photography from RIT in 1978. She was employed in the School of Photographic Arts and Sciences at RIT from 1974 to 1989, and served as the Chair of the Applied Photography Program from 1984 to 1987. She was dean and full professor in the School of Art and Design at Alfred University from 1989 to 1996. She is currently President of the Kansas City Art Institute and has been since 1996. Her work has been shown nationally in numerous group and solo shows and is included in numerous collections, including the Art Institute of Chicago, Chicago Historical Society, Cleveland Art Museum, Chrysler Museum, Indiana University Art Museum, and the Centro Cultural/Arte Contemporaeno in Mexico City. She is the recipient of the "Focus/Infinity Fund' grant for the photo documentary project, "Changing Chicago"; the 'Unicolor' grant in 1983; National Endowment for the Arts Visual Arts Fellowship in 1979; and the 'Photoworks '79,' in 1979. She has been a part of lectures, symposiums and workshops regionally and nationally and curated several exhibitions, including Spectrum, an invitational national exhibition of fine art color photography, in 1976; Manuel Alvarez Bravo, photographic retrospective, Hartnett Gallery, University of Rochester, 1985; and Arnold, Butler, Matczak and Ranalli, exhibition of photographs, Fosdick-Nelson Gallery, School of Art and Design, Alfred University, in 1994. She has been published in Chicago History (1982); Changing Chicago (1989); and Luz Y Tiempo, a catalogue in conjunction with exhibition Luz Y Tiempo at the Centro Cultural/Arte Contemporaneo, Mexico City, 1995.

Sources:

Kathleen Collins, email to the author, June 1, 2009. 


\section{Ira Current $(1987,1988,1989,1990,1992)$}

American (1910 - 2009)

Ira Current was born in Colorado Springs, Colorado. By 1926 he had begun to photograph and make motion pictures. In 1928, he began to work at Stewart Brothers photo finishing. He graduated from the University of Colorado in 1934 and began to work for Agfa Ansco in Binghamton, New York, as head of various standards and quality control departments. He served as head of the technical department of the US Naval Photographic Science Laboratory during WWII and remained in the US Naval Reserves for several decades. In 1946, he returned to Ansco, then called GAF. He retired as head of the Industrial Photo Division in 1972 and then joined the faculty at RIT where he served as Chair of the Professional Photography Program. He wrote many books and articles on photography and was the co-author of Photographic Materials and Processes. He retired as Associate Professor in 1980 and served as Adjunct Professor until 1987. He was a member of the Society of Motion Pictures and Television Engineers, and served on the editorial staff of the Photographic Society of America for over 42 years. His collection of over 60,000 negatives, slides, prints, as well as 200,000 feet of $16 \mathrm{~mm}$ movies have been given to the archives of the University of Colorado.

\section{Sources:}

Ira Current, Photographic Materials and Processes, (Boston: Focal Press, 1986).

Andrew Davidhazy, "Retired Professors and Past Colleagues from the School of Photographic Arts and Sciences at RIT," Rochester Institute of Technology, http://people.rit.edu/andpph/ipt-giants.html (accessed July 9, 2009).

\section{Andrew Davidhazy (1987, 1988, 1989, 1990, 1991, 1992)}

American (b. Hungary, 1941)

Andrew Davidhazy was born in Hungry, raised in Argentina and moved to Boston in 1957. He received a BS in Photo Illustration from RIT in 1966 and an MFA in Graphic Design in 1968. After graduating, he worked as a technical photographer at the Distillation Research Lab at RIT. He joined the faculty in the School of Photographic Arts and Sciences in 1979. He is the Administrative Chair of the BS degree programs and Chair of the Imaging and Photographic Technology Program. He is a member of many societies, including the Society of Photo-Optical Instrumentation Engineers, International Panoramic Photographers Association, Royal Photographic Society and the Photographic Historical Society. He has been a recipient of an Eisenhart Award for Outstanding Teaching and the recipient of the Raymond C. Bowman Award for excellence in teaching from the Society for Imaging Science and Technology. His work with high-speed photography, pinhole photography, and modified cameras intersects both the technical and artistic sides of photography. 
Sources:

Nancy M. Stuart, "The History of Photographic Education in Rochester, New York, 1960-1980" (PhD diss., State University of New York at Buffalo, 2005).

“Andrew Davidhazy, Professor, Chair," Rochester Institute of Technology, http://www.rit.edu/cias/ritphoto/SPAS-FACULTY/pages/faculty-11.html (accessed July 9, 2009).

Michael Dear $(1988,1989,1990,1991,1992)$

American

Michael Dear attended RIT where he received a BS in Photographic Imaging Systems in 1996 and an MS in Information Technology in 2004. He is currently the Operations Manager for the School of Photographic Arts and Sciences.

Sources:

Michael Dear, email to the author, May 19, 2009.

“Michael Dear," LinkedIn, http://www.linkedin.com/pub/michael-dear/10/88b/680 (accessed July 9, 2009).

Denis Defibaugh $(1988,1989,1990,1992)$

American

Denis Defibaugh received an MS from RIT. He was an Assistant Professor at Texas A\&M University, Commerce and Colorado Mountain College. He is now a tenured professor at RIT and was the Chair of the Advertising Photography Program from 1997 to 2005. Defibaugh lectures internationally and has presented workshops for Yellowstone National Park, Zion National Park, Casper College of Wyoming, Florida A\&M University, SPEOS: Paris, and RIT's T\&E Photography Workshops. He has also personally coordinated workshops in Cuba, Mexico, Indonesia, and Korea. Defibaugh has participated in over 25 solo exhibitions in various institutions. He is currently working on photography projects in Cuba, Dubrovnik, Croatia and Zion National Park. He earned a Fulbright-Hays Travel/Study Grant to Mexico in 1993 for his travel and documentary photography. His first book, The Day of the Dead, was published in 2007. He has been widely published and clients for his advertising and editorial work include UNICEF, National Park Service, Coca-Cola, Polaroid, Delta Airlines, MacGregor, Taylor Wines, Eastman Kodak, and American Express.

Sources:

Denis Defibaugh, email to the author, May 11, 2009. 


\title{
Stephen J. Diehl (1991, 1992)
}

\author{
American
}

Stephen J. Diehl has a BS from the University of Miami, and a BS and MS from RIT. He is currently an Associate Professor in the Imaging and Photographic Technology Program. He specializes in nature photography.

Sources:

“Stephen Diehl, Assoc. Professor," Rochester Institute of Technology, http://www.rit.edu/cias/photo/ipt-faculty/ipt-faculty-diehl.html (accessed July 9, 2009).

William DuBois $(1987,1988,1991,1992)$ American

William DuBois received a BFA in Commercial Photography from Ohio University in 1967 and an M.Ed. in Career and Technology Education from Bowling Green State University in 1974. He has been a faculty member in the School of Photographic Arts and Sciences at RIT since 1974. During that time he has been program chair of five of the six undergraduate photography programs, recently served as Administrative Chair of the total School of Photographic Arts and Sciences for ten years, and is presently the Chair of the Visual Media Program. He is a member of the Society for Photographic Education and the Photo Imaging Education Association. His commercial career began in 1967. He specializes in architectural photography and is the co-owner and operator of Images \& Ideas, a full service architectural photography firm for architects, interior designers and contractors that has been around since 1986.

\section{Sources:}

William DuBois, email to the author, May 11, 2009.

"William DuBois," Rochester Institute of Technology, http://www.rit.edu/cias/ritphoto/SPAS-FACULTY/pages/faculty-20.html (accessed July 9, 2009).

\section{Lothar Engelmann $(1987,1988,1989)$}

\author{
American (b. Germany, 1926)
}

Dr. Lothar Engelmann became interested in photography as a student in Frankfurt, Germany. In 1952, after receiving his Master's, he began to work for ADOX where he was able to help develop the first thin emulsion film KB14 and later a whole complement of photographic papers. He was also able to complete his Doctorate degree in 1955. In 1957, he and his wife emigrated to the United States where he worked as a research chemist and manager for such companies as Polaroid, Photek and 3M. In 1966, 3M 
transferred him to Rochester where he was invited by members of the RIT faculty to give seminars to photo-science students. In 1969, he replaced C.B. Neblette as Dean of the College of Graphic Arts and Sciences. After almost 15 years, he gave up his dean position and taught photographic chemistry until his retirement in 1994 . He currently lives with his wife Waltraud in Cologne, Germany.

\title{
Sources:
}

Andrew Davidhazy, "Retired Professors and Past Colleagues from the School of Photographic Arts and Sciences at RIT," Rochester Institute of Technology, http://people.rit.edu/andpph/ipt-giants.html (accessed July 9, 2009).

Nancy M. Stuart, "The History of Photographic Education in Rochester, New York, 1960-1980" (PhD diss., State University of New York at Buffalo, 2005).

Lothar Engelmann, email to the author, July 29, 2009.

\section{William Fischer (1992)}

\author{
American
}

William Fischer taught at RIT from 1990 to 1996 . He was an ophthalmic photographer and taught in the Biomedical Photographic Communications Program.

Sources:

Michael Peres, in discussion with the author, June 2, 2009

\section{Amy Friend (1990)}

American (b. 1966)

Amy Friend was in the Biomedical Photographic Communications Program as RIT from 1985 to 1989. After her freshman year, she worked as a teaching assistant for first year biomedical photo students. In 1990, she was a graduate student studying for an MS degree at RIT. During this time she taught part time in the Biomedical Photographic Communications Program as adjunct faculty. She was actively involved in the Biological Photographic Association and one of the co-founders of the RIT Biomedical Photo Student Association. She won several awards from the BPA for various nature, macro and photomicroscopy images. She currently works for Carestream Health, Inc., a manufacturer of health imaging products and services. She manages the Technical Communications \& Localization department where they create, localize, manage, and deploy various product communications and training.

\section{Sources:}

Amy Friend, email to the author, May 20, 2009. 


\section{Duane Hansen $(1987,1988)$}

American

Duane Hansen was a Facilities Manager for the School of Photographic Arts and Sciences at RIT.

Sources:

Michael Peres, in discussion with the author, June 2, 2009

Mark Haven $(1987,1988,1989)$

American

Mark Haven has a BA from Lebanon Valley College. He went to New York Law School from 1964 to 1965 but left to become a photographer. He studied with Garry Winogrand in 1969 and Diane Arbus in 1971. He has taught workshops for the International Center for Photography, US Navy/Airforce and the Toscana Photographic Workshop. He has produced work for such clients as New York Futures Exchange, American Express, AT\&T and Phillip Morris. His work has appeared in Zoom, Nest, Society, Print, Color Photography, DoubleTake and many other publications. From September 1991 to August 1993, Haven lived in and documented Harper Park, a mobile home community outside of Rochester. His photographs are in numerous collections, including the New York Public Library, which purchased several of his photographs from "Harper Park." He has consulted for Eastman Kodak, Focal Press, and Henoch Gallery, New York City. He has been exhibited internationally and received many honors and awards, including a Minolta Corporation Support Grant, 1978; Hammermill Paper Award, 1981 and the Desi Award, 1983. He has been an Assistant Professor at RIT since 1985.

\section{Sources:}

RIT News \& Events, “Newsmakers,” Rochester Institute of Technology, http://www.rit.edu/news/newsevents/1996/May02/story.php?file=newsmakers (accessed July 9, 2009).

"SPAS Faculty On Line: Mark Haven," Rochester Institute of Technology, http://www.rit.edu/cias/ritphoto/faculty-work/pages/haven-1.html (accessed July 9, 2009).

Mark Haven, "Harper Park," Musarium, http://www.musarium.com/HARPER/Harper2.html (accessed July 9, 2009).

School at ICP Continuing Education, "Faculty," International Center of Photography, http://shopping.icp.org/school/continuing/instructors.html?index=1 (accessed July 9, 2009). 
Mark Haven, email to the author, July 30, 2009.

\title{
John Head (1987)
}

\author{
American
}

John Head received an MFA from RIT. He was an Assistant Professor at RIT and had a major part in running the Reedy Lecture Series, which brought in people such as Lou Dorfsman, Will Hopkins, Duane Michaels, Horst P. Horst, Michael O'Neill, and Mary Ellen Mark. His work has been widely exhibited.

\section{Sources:}

RIT Photography Workshops (Rochester, NY: RIT, 1986).

\section{Jack Holm $(1988,1989,1990)$}

\author{
American
}

John Holm received a BS in Physics from Texas A\&M University and an MS in Imaging Science from RIT. He was an Assistant Professor at RIT from 1987 to 1994, where he taught technical photography. He worked as a color science consultant for companies such as NASA, Kodak and Polaroid. He was Principal Color Scientist at Hewlett-Packard from 1997 to 2008. Holm specializes in digital photography, imaging standards, and color management. He created the first camera raw processing application with user interface for controlling processing steps and automated, image-specific color rendering. He invented the image-specific color rendering processing found in HP digital cameras and is a major contributor to the development of digital photography standards.

Sources:

"Picture Perfect: Jack Holm," Hewlett Packard, http://www.hpl.hp.com/news/2001/aprjun/jackholm.html (accessed July 9, 2009).

"Jack Holm," LinkedIn, http://www.linkedin.com/pub/jack-holm/9/36b/bb5 (accessed July 9, 2009).

\section{David Joseph $(1987,1988,1989,1990,1991,1992)$}

\section{American}

David Joseph graduated from Cornell University in 1978 and received an MFA from RIT in 1986. He was a technical associate at RIT's School of Photographic Arts and Sciences and part of the adjunct faculty for the College of Continuing Education. He also taught photography, printing, and art in junior high and high schools. His work has been exhibited regionally and nationally. 
Sources:

RIT Photography Workshops (Rochester, NY: RIT, 1986).

RIT Photography Workshops (Rochester, NY: RIT, 1987).

Bob Kayser $(1987,1988,1989,1990,1991,1992)$

American

Bob Kayser was born in New York City. He went to The City College of New York and graduated with a degree in education in 1957 . He joined the army and was on active duty for two years in Germany and the in the reserves for two years. He then worked for several photofinishing companies, including Technicolor, Brekey Photo, and Combo Photo. He began to work at RIT in 1971 and retired in 1998.

\section{Weston Kemp $(1987,1988,1989,1990)$}

American (b. 1936)

Weston Kemp was born in Springfield, Vermont. He was in the military for three years and then, with the help of the GI Bill, went to RIT in 1956. He graduated there with a BFA in 1960 and began to work in the Research and Development Group for Polaroid. In 1963, he left Polaroid and began to freelance for National Geographic and other publications, traveling in over fifty countries on four continents. He joined the faculty at RIT in 1968 and received an MFA from there in 1974. During his years at RIT, he taught courses in photography, publishing, picture researching and electronic imaging. In 1974 and 1975, as part of a teaching exchange, he taught at Nottingham Polytechnic University in England. He also spent a year doing post-graduate research and teaching at the University of Maryland. He is currently completing a photo book on Stonehenge and beginning work on a new book about artists in Key West. He is the author of Photography for Visual Communicators and three mass-market photographic manuals. He retired from RIT in 1995 and lives with his wife Lynne Bentley-Kemp in the Florida Keys.

Sources:

Nancy M. Stuart, "The History of Photographic Education in Rochester, New York, 1960-1980" (PhD diss., State University of New York at Buffalo, 2005).

"Weston Kemp, Photographer, Professor, Writer," Weston Kemp, http://www.bentley-kemp.com/Weston/about_wes.html (accessed July 9'2009). 


\section{Dan Larkin $(1990,1991,1992)$}

American (b. 1955)

Dan Larkin received a BFA in Photographic Illustration from RIT in 1983 and an MFA in Photography from Bard College in 1994. He joined the faculty at RIT in 1991 and is currently an Associate Professor and Chair of the Fine Art Photography Program in the School of Photographic Arts and Sciences. He is a member of the College Art Association, National Association of Photoshop Professionals and the Society for Photographic Education. He has lectured nationally and taught at the University of Miami and Miami-Dade Community College. He has had group and solo shows in Rochester, Minneapolis, Philadelphia, New Haven, and Connecticut, and Switzerland.

Sources:

Dan Larkin, email to the author, May 27, 2009.

"Dan Larkin, Associate Professor, Chair," Rochester Institute of Technology, http:/www.rit.edu/cias/ritphoto/SPAS-FACULTY/pages/faculty-21.html (accessed July 9, 2009).

Dan Larkin, http://danlarkin.net (accessed July 9, 2009).

\section{Martha Leinroth (1987)}

American

Martha Leinroth received a BA in Art History from Wellesley College in 1974 and an MFA from the Rhode Island School of Design in 1980. She has been a recipient of the National Endowment for the Arts Visual Artists Grant and a Fellow at The MacDowell Colony. She was an Adjunct Professor at Northeastern University from 1982 to 1984. She was an Assistant Professor at RIT in the School of Photographic Arts and Sciences from 1984 to 1993 . There she taught advertising and fine art photography and developed digital imaging courses. She was also the Chair of the Fine Art Photography Program from 1992 to 1993. She was a trainer at Publications Directions from 1993 to 1996 and at I.M.A.G.E. Inc from 1996 to 2002. She was also an adjunct instructor at New School University from 1996 to 2006, where she taught Photoshop, InDesign, Illustrator, Digital Prepress and HTML at the Computer Instruction Center. She currently works as a Digital Publishing Consultant and Trainer at Time Inc.

\section{Sources:}

"Martha Leinroth," LinkedIn, http://www.linkedin.com/pub/martha-leinroth/a/940/7a5 (accessed July 9, 2009). 


\section{Howard Lester $(1990,1991)$}

American

Howard Lester received a BA and an MFA from UCLA. He is primarily a filmmaker but also an active still photographer. He has received over 40 national and international awards for his films that include comedies, documentaries, animation, and experimental work. Lester spent 18 years in Los Angeles working as editor, director and in all areas of film and video production, as well as three years on the motion picture faculty of UCLA. He began teaching filmmaking at RIT in 1985.

\section{Sources:}

"School of Film \& Animation: Faculty Full Time," Rochester Institute of Technology, http://cias.rit.edu/ sofa/faculty/ft.html (accessed July 9, 2009).

Howard Lester, email to the author, June 2, 2009.

\section{Howard LeVant (1988)}

American (b. 1936)

Howard LeVant is originally from Chicago. In 1958, he received a BA in Photography from Illinois Institute of Technology where he studied with Harry Callahan and Aaron Siskind. He worked as a photographer for major design and photography studios in Cleveland and Chicago until he opened his own advertising photography studio, LeVant Photography, in 1964. He worked with some of the biggest advertising agencies until 1978 when he moved with his wife and three children to Rochester. There he became a full time faculty member at RIT and received a MA in Instructional Technology. He was also an active freelance advertising illustrator. He retired from RIT in 2003. He is on the boards of the Yates County Arts Center and the Finger Lake Chamber Music Festival in Penn Yan, New York. He volunteers at Strong Hospital, teaches computer skills to senior citizens in Rochester through SeniorNet, and still shoots assignments, often pro bono, for not-for-profit organizations.

Sources:

"Howard LeVant, Professor Emeritus," Rochester Institute of Technology, http://www.rit.edu/cias/ritphoto/SPAS-FACULTY/pages/faculty-23.html (accessed July 9, 2009).

Andrew Davidhazy, "Retired Professors and Past Colleagues from the School of Photographic Arts and Sciences at RIT," Rochester Institute of Technology, http://people.rit.edu/andpph/ipt-giants.html (accessed July 9, 2009).

RIT Photography Workshops (Rochester, NY: RIT, 1987). 


\section{Howard Lester $(1990,1991)$}

American

Howard Lester received a BA and an MFA from UCLA. He is primarily a filmmaker but also an active still photographer. He has received over 40 national and international awards for his films that include comedies, documentaries, animation, and experimental work. Lester spent 18 years in Los Angeles working as editor, director and in all areas of film and video production, as well as three years on the motion picture faculty of UCLA. He began teaching filmmaking at RIT in 1985 .

\section{Sources:}

"School of Film \& Animation: Faculty Full Time," Rochester Institute of Technology, http://cias.rit.edu/ sofa/faculty/ft.html (accessed July 9, 2009).

Howard Lester, email to the author, June 2, 2009.

\section{Howard LeVant (1988)}

American (b. 1936)

Howard LeVant is originally from Chicago. In 1958, he received a BA in Photography from Illinois Institute of Technology where he studied with Harry Callahan and Aaron Siskind. He worked as a photographer for major design and photography studios in Cleveland and Chicago until he opened his own advertising photography studio, LeVant Photography, in 1964. He worked with some of the biggest advertising agencies until 1978 when he moved with his wife and three children to Rochester. There he became a full time faculty member at RIT and received a MA in Instructional Technology. He was also an active freelance advertising illustrator. He retired from RIT in 2003. He is on the boards of the Yates County Arts Center and the Finger Lake Chamber Music Festival in Penn Yan, New York. He volunteers at Strong Hospital, teaches computer skills to senior citizens in Rochester through SeniorNet, and still shoots assignments, often pro bono, for not-for-profit organizations.

\section{Sources:}

"Howard LeVant, Professor Emeritus," Rochester Institute of Technology, http://www.rit.edu/cias/ritphoto/SPAS-FACULTY/pages/faculty-23.html (accessed July 9, 2009).

Andrew Davidhazy, "Retired Professors and Past Colleagues from the School of Photographic Arts and Sciences at RIT," Rochester Institute of Technology, http://people.rit.edu/andpph/ipt-giants.html (accessed July 9, 2009).

RIT Photography Workshops (Rochester, NY: RIT, 1987). 


\title{
Judy Levy (1987)
}

American

Judy Levy received a BA in Fine Arts from Ohio State University in 1960. She has also studied printmaking and photography at the Pratt Institute, City College of New York and the Visual Studies Workshop. She taught at Keystone College from 1974 to 1984. Except for a brief stint teaching at Alfred University from 1990 to 1993, she has been teaching art, photography and mixed media at RIT since 1986.

\section{Sources:}

“Academic History.” Judy Levy, http://therealjudylevy.com/ed-exp.html (accessed July 9, 2009).

The Museum System, George Eastman House Collections Management System (accessed July 9, 2009).

\section{J. (Thomas) Tomas Lopez (1992)}

\author{
American (b. Cuba)
}

J. Tomas Lopez has degrees in Psychology and Philosophy from Fordham University, an MMA in Film and Video and an MFA in Photography and Modernist Theory from the University of South Florida. He was part of the faculty at RIT from 1991 to 1994 . He joined the faculty at the University of Miami in 1994 and is currently a professor in the Department of Art and Art History and the head of Electronic Media. He is a recipient of the Florida Individual Artists Grant, the Cintas Foundation Fellowship, and the National Endowment of the Arts Award in the Visual Arts. He has participated in over 175 group exhibitions and over 30 solo exhibitions. His work is included in many permanent collections, such as the Library of Congress, the Smithsonian Institute, the National Gallery of American Art, and La Biblioteque Nationale de France. His work has been exhibited internationally and is known for his large-scale digital prints, underwater photography, politically charged flags, and subway photography. He was the Section Editor for the "Cotemporary Issues" section of the fourth edition of The Focal Encyclopedia of Photography.

Sources:

J. Tomas Lopez, email to the author, May 20, 2009.

\section{Russ Lunn $(1987,1988)$}

American

Russ Lunn graduated from RIT in 1983 with a custom-made degree in photography and videography. This degree paved the way for RIT's film and video major and he later became a Technical Associate and an adjunct faculty member in the Film and Video 
Program at RIT. He has made many independent videos and done video research on computer-generated information displays. His video magazine Wild Future appeared on Rochester cable access and his video Deconstruction was screened at the Rochester Finger Lakes Exhibition.

\title{
Sources:
}

RIT Photography Workshops (Rochester, NY: RIT, 1987).

\section{Jim Megargee (1988)}

\author{
American
}

Jim Megargee began his career in photography in 1966 when he was a photographer in the US Army. He attended the San Francisco Art Institute from 1970 to 1971, where he majored in photography. He then returned to his hometown of Phoenixville, PA, a small steel community, where he documented its changing social and economic conditions for three years. While in Phoenixville, he began to teach photography at a community college. He then moved to Penobscot, Maine where he began to freelance for the Maine Times, Wooden Boat Magazine, and worked as a carpenter. In 1977, he moved to Winter Park, Florida where he began to teach photography at Velencia and Seminole Community Colleges and the Crealde School of Art. In 1979, he became director of the photography program at the Crealde School of Art and then after a year he became director of the school. Six years later, he took the position of Director of Photography at Modesto Community College in California. From 1983 to 1989, he was a professor in the School of Photographic Arts and Sciences at RIT, where he taught all aspects of photography. He became the in-house master printer for Annie Leibovitz for four years before he cofounded MV Labs. Today he works for MV Labs and continues to be an active documentary photographer.

\section{Sources:}

"Bio," Jim Megargee, http://www.jimmegargee.com/jimmegargee/bio.html (accessed July 9, 2009).

\section{Glenn Miller (1988, 1989, 1990, 1991, 1992)}

\section{American}

Glenn Miller has a BS from RIT. He is currently an Associate Professor in the Imaging and Photographic Technology Program at RIT. He specializes in color photography, science and theory. His other interests are railroads and watercolor painting.

\section{Sources:}

"Glenn Miller, Assoc. Professor," Rochester Institute of Technology, http://www.rit.edu/cias/photo/ipt-faculty/ipt-faculty-miller.html (accessed July 9, 2009). 
"SPAS Faculty On Line: Glenn Miller," Rochester Institute of Technology, http://www.rit.edu/cias/ritphoto/faculty-work/pages/miller-1.html (accessed July 9, 2009).

Wes Morningstar $(1987,1988,1989,1990,1991,1992)$ American

Wes Morningstar received a BS from RIT. He was adjunct faculty and then became full time faculty in 1988. He left RIT in 1993. He was the principal illustrator for the third edition of The Focal Encyclopedia of Photography and Photographic Materials and Processes.

Sources:

Michael Peres, in discussion with the author, June 2, 2009

\section{Judy Natal $(1987,1988)$}

American (b. 1953)

Judy Natal was born in Chicago. She received a BFA in Design and Photography from the University of Kansas, Lawrence in 1975 and an MFA in photography from RIT in 1978. She has taught photography at RIT, Alfred University and Syracuse University. She is the recipient of numerous grants and fellowships, including a Fulbright Travel Grant, Illinois Arts Council Photography Fellowships, Polaroid Grants and New York Foundation for the Arts Photography Fellowships. She has work in many permanent collections, including the California Museum of Photography, Center for Creative Photography, Museum of Contemporary Photography, and George Eastman House. She is the author of EarthWords (2004) and Neon Boneyard Las Vegas A-Z (2006). Natal has been exhibited in numerous solo and group shows at such places as Projects International, Photograph Gallery, the Nelson Atkins Museum, the Kathleen Ewing Gallery, and the Sao Paulo Biennale. She has been a professor at Columbia College Chicago since 1997.

Sources:

Judy Natal, http://www.judynatal.com (accessed July 9, 2009)

\section{Elaine O’Neil $(1991,1992)$}

American (b. 1946)

Elaine O'Neil was born in Meriden, Connecticut. She received a BFA in Photography from Philadelphia College of Art in 1968 and an MS in Photography from the Chicago Institute of Design in 1970. She also attended the University of Illinois, Chicago in 1970 and the Northeastern State College, Chicago in 1971. In 1975, she began to teach at the School of the Museum of Fine Arts, Boston. She is married to photographer Allen K. 
Hess. O'Neil has been the recipient of many awards and grants, including The Print Center, Donald \& Ann McPhail Purchase Award; New York Foundation for the Arts and Artists Fellowship; National Endowment for the Arts Photography Fellowship and Massachusetts Council for the Arts Fellowship. She has also given numerous lectures and workshops in the United States, Brazil, England, Australia and Israel. She retired from RIT at the end of the 2007-2008 academic year.

\title{
Sources:
}

The Museum System, George Eastman House Collections Management System (accessed July 9, 2009).

Andrew Davidhazy, "Retired Professors and Past Colleagues from the School of Photographic Arts and Sciences at RIT," Rochester Institute of Technology, http://people.rit.edu/andpph/ipt-giants.html (accessed July 9, 2009).

\section{Willie Osterman $(1987,1988,1989,1990)$}

\author{
American (b. 1955)
}

Willie Osterman is currently a professor of photography at RIT where he has worked since 1984. He received a BFA in Photography from Ohio University, Athens and an MFA in Visual Design and photography from the University of Oregon, Eugene. He has taught workshops nationally and internationally and at the Ansel Adams Workshop in Yosemite National Park. He is the former Curator of Photography at the University of Oregon Museum of Art where he received two grants from the National Endowment of the Arts to operate the Oregon Photography Gallery, the oldest gallery in the Northwest dedicated to photography. He has worked with Ansel Adams as a printing assistant to the production of Ansel Adams Special Edition Prints. Osterman has had over 80 exhibitions throughout the United States since 1977, as well as Italy, Austria, Turkey and Croatia. He has worked for the Eastman Kodak Company photographing and teaching for five summers in the National Park System. In 1990, as part of the centennial celebration of Yosemite National Park, he received a grant from Eastman Kodak, the Ansel Adams Gallery and the Yosemite Association to produce a re-photographic survey and documentation of Yosemite National Park. In 1997 and 1998, he went on sabbatical and spent a year in Italy producing work for his book Deja View: A Cultural Re-Photographic Survey of Bologna, Italy. He is going on sabbatical leave again from RIT with a Fulbright Scholars Grant to travel to the University of Zagreb to help establish its first college level photography program.

Sources:

Willie Osterman, email to the author, May 11, 2009. 
Michael Peres $(1987,1988,1989,1990,1991,1992)$

American (b. 1956)

Michael Peres was born in Utica, New York. He received a BA in biology from Bradley University in 1978, a BS in Biomedical Photographic Communications from RIT in 1982, and an MS in Instructional Technology from RIT in 1991. He joined the faculty of RIT in 1986 and has been the Chair of the Biomedical Photographic Communications Program since 1989. Peres served as editor-in-chief for the fourth edition of The Focal Encyclopedia of Photography and has presented numerous papers and imaging-related workshops all over the United States, as well as in Sweden, Tanzania, the Netherlands, Germany, and Australia. He is a member of the BioCommunications Association and the Ophthalmic Photographers' Society. His professional activities include being one of the coordinators for the annual RIT Big Shot, an annual nigh-time community photography project sponsored by the School of Photographic Arts and Sciences; serving as Chair of the Lennart Nilsson Award Nominating Committee, Stockholm Sweden; and coorganizing the Images in Science exhibition. He is the recipient of the Eisenhart Award for Outstanding Teaching, the Gitner Prize presented by the RIT College of Imaging Arts and Sciences, and the Louis B. Schmidt Award presented by the BioCommunications Association.

\section{Sources:}

"Michael R Peres, Professor, Chair," Rochester Institute of Technology, http://www.rit.edu/cias/ritphoto/SPAS-FACULTY/pages/faculty-10.html (accessed July 9, 2009).

Michael Peres, in discussion with the author, June 2, 2009.

\section{William Peterson $(1987,1988,1989,1990)$}

\section{American}

William Peterson was staff at RIT for many years and then became full-time temporary faculty. He left RIT in the late 1980s or early 1990s.

Sources:

Michael Peres, in discussion with the author, June 2, 2009.

\section{Doug Rea $(1987,1988,1989)$}

American

Doug Rea received a BS from Union College and an MFA in Photography from RIT. He is currently a professor in the Photojournalism Program. He became an adjunct faculty member in 1976 and a full member of the faculty in 1996. Before he came to RIT, Rea was a full-time professional photographer. $\mathrm{He}$ is a pioneer and authority in digital 
photography and digital workflow. He is the founder of RIT's electronic photography lab. He remains an active free-lance photographer for news agencies, corporations and the auto sports industry. He is a member of the National Press Photographers Association and the Amateur Press Association. His work has been shown in over 35 exhibitions all over the United States. He is the author of Preventive Photoshop: Take the Best Digital Photographs Now for Better Images Later, which came out in 2007.

Sources:

"RIT Experts: Digital Photography," Rochester Institute of Technology, http://www.rit.edu/news/index.php?p=experts\&action=viewarea\&id=27 (accessed July 9, 2009).

"Doug Rea," Rochester Institute of Technology, http://www.rit.edu/cias/ritphoto/SPASFACULTY/pages/faculty-25.html (accessed July 9, 2009).

\title{
John W. Retallack $(1987,1988,1989,1990,1991,1992)$
}

\author{
American (b. 1941)
}

John W. Retallack earned a BFA from RIT and later was an Assistant Professor in the School of Photographic Arts and Sciences. He retired at the end of the 2007-2008 academic year. He is the educational liaison for the Western New York Chapter of the American Society of Media Photographers and serves on the chapter governing board, an elected position. His favorite subject to photograph is people. Since 1998, he has been a volunteer artist in residence at Monroe Community Hospital, a care and rehabilitation center for people with physical and mental disabilities. A portfolio of 54 portraits from the MCH was accepted into the Eastman House collection in 2006. He has also been taking portraits of his colleagues over the years.

Sources:

"SPAS Faculty On Line: John Retallack," Rochester Institute of Technology, http://www.rit.edu/cias/ritphoto/faculty-work/pages/retallack-1.html (accessed July 9, 2009).

John Retallack, "Retallack Photography," Rochester Institute of Technology, http://people.rit.edu/jwrpph/ (accessed July 9, 2009).

George Eastman House Acquisition Report (July 26, 2006).

\section{Mark Sager $(1991,1992)$}

American

Mark Sager was born and raised in Rochester. His photographic interests began at the age of fourteen when in his eighth grade science darkroom he witnessed a blank sheet of 
white paper change into a photograph before his eyes. He continued taking photography through high school and went to a two year school that had photography courses. He had intended to transfer to RIT, but due to financial reasons that opportunity never worked out. Nevertheless, he has remained in the photographic field ever since. He worked as a freelance photographer, in photo retail, and at professional color lab called Color Methods/CMI Communications. He has worked for Eastman Kodak, Dryden Press, Eber Brothers and many more companies. He has had his work exhibited regionally and won many photo contests. His passion is the outdoors and this is reflected in his body of work, which includes local nature/scenic work as well as images from the Southwest and the Caribbean Islands. He has worked for RIT for over 15 years and is currently Assistant Operations Manager in the School of Photographic Arts and Sciences.

Sources:

"SPAS Staff On Line: Mark Sager", Rochester Institute of Technology, http://www.rit.edu/cias/ritphoto/faculty-work/pages/sager-1.html (accessed July 9, 2009).

Mark Sager, email to the author, May 14, 2009.

\section{Harvey Stein (1988)}

American (b. 1941)

Harvey Stein grew up in Pittsburg. He has been a member of the faculty of the New School University, Drew University, RIT, and the University of Bridgeport. He began as a professional photographer in 1972 and began teaching it in 1976. He has published numerous books, including Movimento: Glimpses of Italian Street Life (2006), Coney Island (1998), Artists Observed (1986), and Parallels: A Look at Twins (1978). His work has been published in many periodicals, including The New Yorker, Time, Life, Esquire, Smithsonian, The New York Times, Playboy, Camera Arts, Black \& White Magazine, Afterimage and many others. He has widely exhibited nationally and internationally with 71 solo and 137 group shows. His photographs are in the permanent collection of over 50 institutions, including the Bibliotheque Nationale, the Art Institute of Chicago, the New Orleans Museum of Art, the International Center of Photography, the Denver Museum of Art, the Santa Barbara Museum of Art, and several corporate art collections. He was a recipient of the 1982/83 Creative Arts Public Service Fellowship and numerous artist in residency grants. He currently teaches at the International Center of Photography and the School of Visual Arts in New York City.

\section{Sources:}

Harvey Stein, email to the author, June 11, 2009.

Harvey Stein, Artists Observed, (New York: Abrams, 1986).

Harvey Stein, Coney Island, New York: W.W. Norton \& Co., 1998) 


\title{
Loret (Falkner) Steinberg $(1989,1990,1991)$
}

\author{
American
}

Loret Steinberg attended Indiana University, Bloomington where she received a BA in Fine Arts and Journalism in 1983 and an MFA in Photography in 1986. She is the Professional Freedoms and Responsibilities Chair for the Visual Communications Division of the Association for Education in Journalism and Mass Communication and writes a column for the division quarterly publication, ViewPoints. She is also a member of the National Press Photographers' Association. She has taught at RIT since 1988 and is currently an Associate Professor in the Photojournalism Program. She advocates community involvement to her students and teaches them the broader cultural impact and implications of photography. She has taught workshops on civic journalism, visual communication, methods for audience engagement and often works in collaboration with the community. She has photographed extensively at a correctional facility for juveniles where she also taught a photography class as a volunteer. Over several years she has photographed and worked with the homeless in Rochester. An interdisciplinary course she taught, Images for a Social Dialogue, put on a month-long gallery installation, Unseen Neighbors, with speakers and publications that made contributions to community dialogue on homelessness. Her most recent project has been to photograph migrant workers. She frequently lectures and writes on photography and has had her work published and exhibited across the United States. She changed her name from Falkner to Steinberg after she got married in November 1995.

\section{Sources:}

"Loret Gnivecki Steinberg," Rochester Institute of Technology, http:/www.rit.edu/cias/ritphoto/SPAS-FACULTY/pages/faculty-24.html (accessed July 9, 2009).

“SPAS Faculty On Line: Loret Steinberg," Rochester Institute of Technology, http://www.rit.edu/cias/ritphoto/faculty-work/pages/steinberg-1.html (accessed July 9, 2009).

"RIT Experts: Loret Steinberg," Rochester Institute of Technology, http://www.rit.edu/news/index.php?p=experts\&action=viewexpert\&id=7 (accessed July 9, 2009).

Nancy M. Stuart (1987, 1988, 1989, 1990, 1991, 1992)

American (b. 1954)

Nancy M. Stuart began teaching photography at Lansing Community College in 1975. She has presented at the East Lansing Arts Workshop, Taylor Publishing Company, and the Maine Photographic Workshop. From 1984 to 2002 she held various positions as part of the faculty of the School of Photographic Arts and Sciences at RIT, including 
Associate Professor of Photography, Chair of the Applied Photography Program, Associate and Acting Director of the School of Photographic Arts and Sciences, and Associate Dean of the College of Imaging Arts and Sciences. She completed her PhD at the State University of New York, Buffalo in the Graduate School of Education. Her dissertation was on the History of Photographic Education in Rochester, NY from 1960 to 1980 . Her photography often focuses on portraiture and she has work in the Eastman House collection. One portrait from her book DES Stories: Faces and Voices of People Exposed to Diethylsitbestrol (2001) was chosen for the John Kobal Portrait Award Exhibit at the National Portrait Gallery in London. She was a section editor for the fourth edition of The Focal Encyclopedia of Photography. She is currently the Executive Vice President and Provost of The Cleveland Institute of Art.

Sources:

Michael R. Peres, ed. The Focal Encyclopedia of Photography: Digital Imaging, Theory and Applications, History and Science, $4^{\text {th }}$ ed. (New York: Focal, 2007).

RIT Photography Workshops (Rochester, NY: RIT, 1987).

Nancy M. Stuart, email to the author, May 14, 2009.

John Trauger $(1987,1988,1989,1990,1991,1992)$ American (d. 2007)

John Trauger served for eighteen years as a corporate photographer for Standard Oil Company of Ohio and two years as a supervisor of photography at Corning Glass. His photographic work has included annual reports, scientific work, portraiture, and aerial photography. He played an important role in establishing the Biomedical Photographic Communications Program in 1970. He died at the age of 91 in October 2007.

Sources:

RIT Photography Workshops (Rochester, NY: RIT, 1986).

Andrew Davidhazy, "Retired Professors and Past Colleagues from the School of Photographic Arts and Sciences at RIT," Rochester Institute of Technology, http://people.rit.edu/andpph/ipt-giants.html (accessed July 9, 2009).

Mark Watts $(1987,1988,1989,1990,1992)$

American

Mark Watts was a Facilities Coordinator in the School of Photographic Arts and Sciences at RIT. He received a Masters in Information Technology from RIT. He was faculty in the School of Print Media until 2005 or 2006. 
Sources:

Michael Peres, in discussion with the author, June 2, 2009.

Amy (Smith) Weiner (1988, 1989, 1990, 1991)

American

Amy Weiner was the Budget Secretary for the School of Photographic Arts and Sciences.

She changed her name from Smith to Weiner after she got married.

Sources:

Michael Peres, in discussion with the author, June 2, 2009.

Ken White $(1987,1988,1989,1990,1991,1992)$

American (b. 1950)

Ken White received a BA from Princeton and an MFA in Art Photography from the University of New Mexico in 1978. He has been a member of the faculty at RIT since 1984 and served as Chair of the Fine Art Photography Program for 14 years. He teaches art photography critiques, portraiture, introduction to post-modernism, photo history and aesthetics. He has taken RIT students to Paris for three summers and the US Southwest for 17 summers. His main photographic interests are self-portraiture, the Southwest, and camera obscura. He is also a member of the Society for Photographic Education.

Sources:

Ken White, "Ken White," Rochester Institute of Technology, http://www.rit.edu/cias/rit photo/SPAS-FACULTY/pages/faculty-13.html (accessed July 9, 2009).

\section{Richard Zakia (1987)}

American (b. 1925)

Richard Zakia was born in Rochester, New York. In high school he learned to be a welder and worked for Kodak for a short time before being called to service by the US Navy. He was rejected by the University of Rochester for admission but then met with C.B. Neblette and was accepted into the RIT photography program on probation. $\mathrm{He}$ graduated from RIT in 1956 with a BS in Photographic Science. In 1958, he began to work for Kodak as a photographic engineer in the Color Technology Division but then was convinced by Neblette to teach photography at RIT. He taught photographic science until 1969. He earned an Ed.D. in Educational Psychology from the University of Rochester in 1970 and also began to serve as Director of Instructional Research and Development at RIT. He rejoined the photography faculty in 1976 and became coordinator of the MFA photography program and Chair of the Fine Art Photography 
Program for many years. He retired from RIT in 1992. He has authored and co-authored several books about photography, visual perception, semiotics and advertising, including Photographic Sensitometry, with Hollis Todd (1969), 101 Experiments in Photographys, with Todd (1969) Zone Systemizer, with John Dowdell (1973), Perception and

Photography (1974), The New Zone System Manual, with Minor White and Peter Lorenz (1976), Visual Concept for Photographers (1980), Perceptual Quotes for Photographers (1980), Teaching Photography with Dr. Glenn Rand (2006), and he wrote the section "Snapshot Photography, Perception, Evidence, Truth, and Seeing" in the fourth edition of The Focal Encyclopedia of Photography.

Sources:

Zakia, email to the author, May 23, 2009.

Nancy M. Stuart, "The History of Photographic Education in Rochester, New York, 1960-1980" (PhD diss., State University of New York at Buffalo, 2005).

Turner Browne, MacMillan Biographical Encyclopedia of Photographic Artists \& Innovators, (New York: Macmillan, 1983).

Michael R. Peres, ed. The Focal Encyclopedia of Photography: Digital Imaging, Theory and Applications, History and Science, $4^{\text {th }}$ ed. (New York: Focal, 2007). 


\section{Appendix B}

\section{Inventory of the Six Portfolios From the Faculty and Staff of the School}

\section{of Photographic Arts and Sciences at Rochester Institute of Technology,}

\section{May 1987 - May 1992}

The following is a complete inventory of the six portfolios in the original order in which the prints were found. The inventory includes the photographer's name, title, date (with the date printed in parentheses, if applicable), process, image dimensions, overall dimensions, and any possible recto or verso inscriptions for each print.

\section{Rochester Institute of Technology School of Photographic Arts and Sciences Faculty and Staff Portfolio, May 1987}

Martha Leinroth

Untitled (Seated woman talking to man on beach in front of graffiti-covered wall), c. 1987

color print, chromogenic development process

image: $13.5 \times 33.5 \mathrm{~cm}$ overall: $27.9 \times 35.4 \mathrm{~cm}$

recto inscription: (black ink): [signed] Martha Leinroth

John W. Retallack

Untitled (Andrew Davidhazy holding camera contraption in wooden frame), 1987 gelatin silver print

image: 26.5 x $26.2 \mathrm{~cm}$ overall: 35.4 x $27.7 \mathrm{~cm}$

recto inscription: (black ink): [signed] JWR 87

in acetate

Doug Rea

Untitled (Pink flowers behind short white fence), c. 1987

color print, chromogenic development process

image: 22.2 x $22.1 \mathrm{~cm}$ overall: $35.4 \times 27.8 \mathrm{~cm}$

recto inscription: (black ink): [signed] Douglas Ford Rea 


\section{Willie Osterman}

Untitled (Boy and girl playing in creek with sticks and stones), c. 1987

gelatin silver print

image: 17.4 x $26.8 \mathrm{~cm}$ overall: 27.8 x $35.3 \mathrm{~cm}$

recto inscription: (pencil): [signed] Willie Osterman 21/35

in glassine

David Joseph

Untitled (Men's white suits in store window), c. 1987

color print, chromogenic development process

image: 24 x $24 \mathrm{~cm}$ overall: $35.4 \times 27.8 \mathrm{~cm}$

recto inscription: (black ink): [signed] David J Joseph

Mark Haven

Brighton, New York, 1986

gelatin silver print

image: 19 x $27.6 \mathrm{~cm}$ overall: 23.6 x $35.3 \mathrm{~cm}$

verso inscription: (pencil): (c) [signed] Mark S Haven 1986 Brighton, N.Y.

Guenther Cartwright

Drax Power Station, North Yorkshire, UK, 1986

color print, chromogenic development process

Both images: 15.1 x $22.6 \mathrm{~cm}$ overall: 35.4 x $27.8 \mathrm{~cm}$

verso inscription: (black ink): DRAX POWER STATION, NORTH YORKSHIRE, U.K.

[signed] G 86 (stamped in pink ink): (C) GUENTHER CARTWRIGHT

Lothar Engelmann

Untitled (Portrait of first wife using Sabattier effect), 1987

gelatin silver print

image: 34.3 x $26.9 \mathrm{~cm}$ overall: 35.4 × $27.8 \mathrm{~cm}$

verso inscription: (black ink): Lothar Engelmann/ 1987

Owen Butler

Untitled (Hanging wire with metal ring at its end in front of fence with two painted number “1's"), c. 1987

gelatin silver print

image: 25.1 x $20.1 \mathrm{~cm}$ overall: $35.3 \times 27.8 \mathrm{~cm}$

unsigned

Wes Morningstar

Untitled (Red and pink flower painted in center of stone wall painted green), c. 1987

color print, silver dye bleach process

image: 20.4 x $30.7 \mathrm{~cm}$ overall: $27.8 \times 35.5 \mathrm{~cm}$

verso inscription: (black ink): [signed] Wes Morningstar 
Judy Levy

American Bridegroom, 1987

color print, chromogenic development process

image: 20.3 x $29.9 \mathrm{~cm}$ overall: $27.3 \times 35.5 \mathrm{~cm}$

verso inscription: (black ink): "American Bridegroom" [signed] Judith A. Levy 1987

John Head

Untitled (Two men on horses with hunting dogs in woods), c. 1987

color print, chromogenic development process

image: 15.4 x $27.9 \mathrm{~cm}$ overall: 27.8 x $35.4 \mathrm{~cm}$

verso inscription: (black ink): [signed] John Head

Weston Kemp

Untitled (Stones on top of cracked rock with snow covered mountain in background), 1985 (1987)

color print, chromogenic development process

image: 16.1 x $29.3 \mathrm{~cm}$ overall: $27.8 \times 35.4 \mathrm{~cm}$

verso inscription: (black ink): 21/35 (C) [signed] Weston Kemp 1985 (87)

Ira Current

Wheel Yard, 1977

gelatin silver print

image: 20.4 x $29.7 \mathrm{~cm}$ overall: 27.3 x $34.6 \mathrm{~cm}$

verso inscription: (pencil): WHEEL YARD/ (C) 1977/ [signed] Ira Current/ 2660/1930 Se/

\#36

Richard Zakia

Untitled (Mourning doves eating birdseed below bird feeder), c. 1987

color print, silver dye bleach process (Cibachrome)

image: 33.4 × $22.6 \mathrm{~cm}$ overall: $35.3 \times 27.8 \mathrm{~cm}$

unsigned

Michael Peres

Untitled (Half open window in dark room with branches outside), c. 1987

color print, chromogenic development process

image: 25.5 x $25 \mathrm{~cm}$ overall: $35.5 \times 27.8 \mathrm{~cm}$

recto inscription: (black ink): [signed] Michael R Peres

John Trauger

Shrine of the Bab Baha'I World Center, Hafia, Israel, c. 1987

color print, chromogenic development process

image: 34.8 x $27.1 \mathrm{~cm}$ overall: 35.4 x $27.8 \mathrm{~cm}$

verso inscription: (applied printed label): SHRINE OF THE BAB/ BAHA'I WORLD

CENTER, HAFIA, ISRAEL/ PHOTOGRAPH BY JOHN F. TRAUGER 


\section{Greg Barnett}

Untitled (Rock sticking out of water running along stone cliff in Adirondacks), 1987 gelatin silver print image: 20.1 x $27.8 \mathrm{~cm}$ overall: 27.7 x $35.4 \mathrm{~cm}$ recto inscription: (pencil): [signed] GR BT/ 1987

Mark Watts

Untitled (Photogram with "MANDALA" written on the left and "27B" written on the right), c. 1987

gelatin silver print

image: $23.2 \times 28.5 \mathrm{~cm}$ overall: $27.8 \times 35.4 \mathrm{~cm}$

recto inscription: (pencil): [signed] Mark Watts

Andrew Davidhazy

Untitled (Distorted unidentified woman with head band and hand on neck), 1987

gelatin silver print

image: 24.2 × $35.3 \mathrm{~cm}$ overall: $27.8 \times 35.3 \mathrm{~cm}$

verso inscription: (black ink): [signed] A Davidhazy 1987

William DuBois

Untitled (Scarborough Civic Center), c. 1987

color print, silver dye bleach process

image: 15.6 × $20.7 \mathrm{~cm}$ overall: $27.8 \times 35.5 \mathrm{~cm}$

recto inscription: (in print): [signed] William W. Dubois

Nancy M. Stuart

Alan, 1986

gelatin silver print

image: 20.1 x $20.3 \mathrm{~cm}$ overall: $35.3 \times 27.7 \mathrm{~cm}$

recto inscription: (black ink): [signed] Alan

verso inscription: (pencil): (C) Nancy M. Stuart 1986/ 16/40

Ken White

Champaign, Illinois, 1982 (1987)

gelatin silver print

image: 22.1 x $29.9 \mathrm{~cm}$ overall: 27.6 x $35.7 \mathrm{~cm}$

recto: (pencil): Champaign, IL 1982 [signed] Ken White

verso: (pencil): Ken White 1982 ('87)

\section{Duane Hansen}

Untitled (Tree with missing part of trunk with rocks near it), c. 1987

color print, chromogenic development process

image: 33.1 x $13.4 \mathrm{~cm}$ overall: $35.4 \times 27.8 \mathrm{~cm}$

verso inscription: (black ink): [signed] Duane $\mathrm{H}$ 
Bob Kayser

Untitled (Dead tree hanging over side of waterfall), c. 1987

color print, chromogenic development process

image: 23.7 x $35.4 \mathrm{~cm}$ overall: $27.8 \times 35.5 \mathrm{~cm}$

verso inscription: (black ink): [signed] Robert Kayser

William Peterson

Untitled (Woman swimming with underwater plants in foreground), 1987

gelatin silver print

image: 21.9 x $32.7 \mathrm{~cm}$ overall: $27.8 \times 35.4 \mathrm{~cm}$

verso inscription: (pencil): 1987/ C [signed] W R Peterson

Russ Lunn

Untitled (Wooden pole on beach with other poles in background), c. 1987

gelatin silver print

image: 20.2 x $25.5 \mathrm{~cm}$ overall: 27.8 x $35.4 \mathrm{~cm}$

verso inscription: (pencil): Russ Lunn

Kathleen Collins

Untitled (Alley in Mexico surrounded by white walls and red wall at end), May 1987 color print, chromogenic development process

image: 22.2 x $22.1 \mathrm{~cm}$ overall: 35.4 x $27.8 \mathrm{~cm}$

verso inscription: (black ink): [signed] K Collins 5/87

Judy Natal

Untitled (Dead fish on sand), May 1987

gelatin silver print

image: 15.2 x $22.8 \mathrm{~cm}$ overall: $27.8 \times 35.4 \mathrm{~cm}$

verso inscription: (pencil): Fish Series 13/35 [signed] J. L Natal May 1987

Charles Arnold

Untitled (Abstract black and white with curled leaf), 1987

electrostatic print

image: 21.1 x $19.3 \mathrm{~cm}$ overall: 35.5 x $27.9 \mathrm{~cm}$ mount: 21.5 x $19.3 \mathrm{~cm}$ window: $11.4 \mathrm{x}$ 15.2

recto inscription: (pencil): Charles A. Arnold Jr. 12/40 1987

\section{Rochester Institute of Technology School of Photographic Arts and Sciences Faculty and Staff Portfolio, May 1988}

Bob Kayser

Untitled (Branches sticking out of water with reflection of fall foliage), 1988

color print, chromogenic development process

image: 27.4 x $35.5 \mathrm{~cm}$ overall: 28.2 x $35.9 \mathrm{~cm}$

verso inscription: (black ink): [signed] R Kayser 1988 
William Peterson

Marilyn and Ali, 1981 (1988)

gelatin silver print

image: 21 x $31.2 \mathrm{~cm}$ overall: $27.8 \times 35.3 \mathrm{~cm}$

verso inscription: (pencil): 46/50 "MARilyn \& Ali, 1981" [signed] WR Peterson 1988 (C)

in acetate

Doug Rea

Untitled (Three close-ups images of flowers), 1988

color print, chromogenic development process

image: 11.1 x $9.1 \mathrm{~cm}$ overall: $27.8 \times 35.4 \mathrm{~cm}$

verso inscription: (black ink): (C) 1988 [signed] Douglas Ford Rea

Judy Natal

Untitled (Fish laying sideways with fin sticking out of water), c. 1988

gelatin silver print

image: 11.9 x $16.9 \mathrm{~cm}$ overall: $28 \times 35.3 \mathrm{~cm}$

recto inscription: (pencil): 28/43 [signed] J L Natal

Ken White

Las Vegas, 1980

gelatin silver print

image: 21.4 x $29.1 \mathrm{~cm}$ overall: $27.7 \times 35.3 \mathrm{~cm}$

verso inscription: (pencil): 24/43 Las Vegas, 1980 [signed][illegible]K.W.

Owen Butler

Untitled (Rocks with white object on top), 1988

gelatin silver print

image: 24.4 x $19.3 \mathrm{~cm}$ overall: $35.3 \times 27.8 \mathrm{~cm}$

recto inscription: (black ink): [signed] O Butler ' 88

Willie Osterman

Untitled (Three young girls in polka-dotted and striped dresses each looking through the viewfinder of three small cameras), 1988

gelatin silver print

image: 30.4 x $20.2 \mathrm{~cm}$ overall: $35.2 \times 27.6 \mathrm{~cm}$

recto inscription: (pencil): 24/45 [signed] Willie Osterman ' 88

verso inscription: (stamped in black ink): (C) Willie Osterman

Patti Ambrogi

Untitled (Road in background and blurry pink flowers in foreground), c. 1988

color print, chromogenic development process

image: 27.7 x $35.3 \mathrm{~cm}$ overall: $27.7 \times 35.3 \mathrm{~cm}$

unsigned 
Amy (Smith) Weiner

Untitled (Man sitting on park bench with pigeons next to him), c. 1988

color print, chromogenic development process

image: 31.8 x $25.8 \mathrm{~cm}$ overall: 35.4 × $27.8 \mathrm{~cm}$

verso inscription: (black ink): [signed] Amy Smith

Guenther Cartwright

Heslington, York, England, 1986 (1988)

color print, chromogenic development process

image: 24.8 x $30.3 \mathrm{~cm}$ overall: $27.8 \times 35.4 \mathrm{~cm}$

verso inscription: (stamped in black ink): (C) Guenther Cartwright (black ink): 1988

Heslington, York, England, 1986 [signed] G 88

Howard LeVant

Untitled (Matador and bull in blurred motion), c. 1988

color print, chromogenic development process

image: 24 x $35.2 \mathrm{~cm}$ overall: $27.7 \times 35.2 \mathrm{~cm}$

recto inscription: (black ink): [signed] LeVant

Lynne Bentley-Kemp

May Field, c. 1988

gelatin silver print

image: 16.8 x $25.3 \mathrm{~cm}$ overall: $27.8 \times 35.3 \mathrm{~cm}$

recto inscription: (pencil): May field [signed] L. Bentley-Kemp

Weston Kemp

Untitled (Circle of people in white robes in middle of Stonehenge), 1987

gelatin silver print

image: $19.9 \times 29.9 \mathrm{~cm}$ overall: $27.6 \times 35.3 \mathrm{~cm}$

verso inscription: (stamped in blue ink): CWeston D. Kemp (pencil): 1987

David Joseph

Untitled (Skyliner rollercoaster in field of snow), May 1988

color print, chromogenic development process

image: $16.1 \times 31.6 \mathrm{~cm}$ overall: $27.8 \times 35.5 \mathrm{~cm}$

verso inscription: (black ink): [signed] David J Joseph 5/88

Mark Haven

Untitled (Cars lined up in front of fake western background in Venice Beach, California), c. 1988

color print, chromogenic development process

image: 22.4 x $32.9 \mathrm{~cm}$ overall: $27.8 \times 35.5 \mathrm{~cm}$

verso inscription: (stamped in black): CMARK HAVEN 
John W. Retallack

Untitled (Hand reaching for white rose), 1988

gelatin silver print

image: $14.1 \times 11.7 \mathrm{~cm}$ overall: $35.4 \times 27.8 \mathrm{~cm}$

verso inscription: (black ink): (1988 J.W. RETALLACK

Nancy M. Stuart

Untitled (Woman sitting on bed with child on her lap), 9/27/1987

gelatin silver print

image: 21.5 x $21.6 \mathrm{~cm}$ overall: $35.2 \times 28 \mathrm{~cm}$

verso inscription: (pencil): Nancy M. Stuart/ 9/27/87

Ira Current

Winter Road, 1936

gelatin silver print

image: 20.4 × $29.7 \mathrm{~cm}$ overall: $27.5 \times 34.7 \mathrm{~cm}$

verso inscription: (pencil): WINTER ROAD/ [signed] Ira Current/ 13731B/ 1936/ \#22

Greg Barnett

Untitled (Waterfalls going down rock cliffs in Adirondracks), 1988

gelatin silver print

image: $23.3 \times 23 \mathrm{~cm}$ overall: $35.3 \times 28 \mathrm{~cm}$

verso inscription: (pencil): [signed] Greg Barnett ' 88

Harvey Stein

Rochester Polka Club Dance, 1987 (1988)

color print, chromogenic development process

image: 23.5 x $32.7 \mathrm{~cm}$ overall: 27.8 x $35.4 \mathrm{~cm}$

verso inscription: (black ink): Rochester Polka Club Dance, 1987 [signed] Harvey Stein, 1988

Charles Arnold

Untitled (Abstract with rock and shell), 1988

electrostatic print

image: 21.5 x $27.8 \mathrm{~cm}$ overall: 21.2 x $27.8 \mathrm{~cm}$ mount: $35.8 \times 27.8 \mathrm{~cm}$ cover: $27.9 \times 21.5$

$\mathrm{cm}$

recto inscription: (white ink): [signed] CHARLIE ARNOLD 1988

Denis Defibaugh

Untitled (Forest of branchless trees), c. 1988

gelatin silver print

image: 17.8 x $22.8 \mathrm{~cm}$ overall: $27.7 \times 35.2 \mathrm{~cm}$

verso inscription: (pencil): [signed] Denny Defibaugh 
Russ Lunn

Untitled (Pixelated face with green grasses), c. 1988

thermal print

Image: 27.5 x $35.4 \mathrm{~cm}$ overall: $27.9 \times 35.5 \mathrm{~cm}$

verso inscription: (black ink): [signed] Russ LUNN

John Trauger

Untitled (Self-portrait in reflective ball on column), c. 1938

gelatin silver print

image: 24.2 x $20.2 \mathrm{~cm}$ overall: $35.4 \times 27.8 \mathrm{~cm}$

recto inscription: (purple ink): [signed] John F. Trauger/c. 1938

Wes Morningstar

Untitled (Cacti, flowers and vegetables on picnic table in front of trees and bushes), May 1988

gelatin silver print

image: 16 x $23.6 \mathrm{~cm}$ overall: $27.7 \times 35.2 \mathrm{~cm}$

verso inscription: (pencil): (C) [signed] Wes Morningstar 5/88

Duane Hansen

Untitled (Trees next to shallow water with dead leaves), April 1988

color print, chromogenic development process

image: 30.6 x $20.4 \mathrm{~cm}$ overall: 35.5 x $27.8 \mathrm{~cm}$

verso inscription: (black ink): Duane Hansen/ 34 of 87 4-88

Skip Battaglia

Untitled (Animation cell from Geologic Time), 1988

art-drawing

image: 17.4 x $24 \mathrm{~cm}$ overall: $26.5 \times 31.5 \mathrm{~cm}$

recto inscription: (pencil): From "Geologic Time" [signed] Skip

Mark Watts

Better Want Than Need, c. 1988

gelatin silver print

image: 22.4 x $29.9 \mathrm{~cm}$ overall: 27.9 x $35.3 \mathrm{~cm}$

recto inscription: (black ink): [signed] Mark Watts

Andrew Davidhazy

Marlene Dietrich, 1960

gelatin silver print

image: 30.7 × $20.6 \mathrm{~cm}$ overall: $35.4 \times 27.8 \mathrm{~cm}$

verso inscription: (black ink): Marlene Dietrich 1960 [signed] A Davidhazy 
Glenn Miller

Untitled (Crowd next to train with man on top), 1988

color print, chromogenic development process

image: 25.3 x $32.9 \mathrm{~cm}$ overall: $27.8 \times 35.5 \mathrm{~cm}$

verso inscription: (black ink): [signed] GCMiller (C1988

Michael Dear

Untitled (River running through forest with fall colors), 1988

color print, chromogenic development process

image: 27.3 x $34.8 \mathrm{~cm}$ overall: $27.7 \times 35.5 \mathrm{~cm}$

verso inscription: (blue ink): [signed] Michael E. Dear "88"

Michael Peres

Untitled (Close-up of a pink flower), May 1988

color print, chromogenic development process

image: 33.2 × $22.9 \mathrm{~cm}$ overall: $35.5 \times 27.8 \mathrm{~cm}$

verso inscription: (green ink): [signed] Michael R. Peres 5.88

Lothar Engelmann

Rochester Snowflakes, February 1988

color print, chromogenic development process

image: $35.4 \times 27.8 \mathrm{~cm}$ overall: $35.4 \times 27.8 \mathrm{~cm}$

verso inscription: (black ink): Rochester Snowflakes/ Feb. 88/ [signed] Lothar

Engelmann

William Dubois

Untitled (Close-up of frost), 1988

gelatin silver print

image: 19.2 x $24 \mathrm{~cm}$ overall: $27.9 \times 35.4 \mathrm{~cm}$

verso inscription: (black ink): [signed] William W Dubois ' 88

Jack Holm

Untitled (Silhouette of tree with hills in background), 1974 (1988)

color print, chromogenic development process

image: $22.7 \times 35.3 \mathrm{~cm}$ overall: $27.8 \times 30.3 \mathrm{~cm}$

verso inscription: (black marker): (C) [signed] Jack Holm 1974/88

Jim Megargee

Albany, NY (published), 1988

gelatin silver print

image: $30.2 \times 20 \mathrm{~cm}$ overall: $35.4 \times 27.8 \mathrm{~cm}$

verso inscription: (pencil): [signed] Jim Megargee 


\section{Rochester Institute of Technology School of Photographic Arts and Sciences Faculty and Staff Portfolio, May 1989}

\section{Doug Rea}

Untitled (Close-up of machine parts), 1989

computer generated

image: $9.1 \times 12 \mathrm{~cm}$ overall: $35.5 \times 27.9 \mathrm{~cm}$

verso inscription: (pencil): (C)1989 [signed] Douglas Ford Rea

\section{Mark Haven}

Untitled (Willie Osterman walking along beach in Daytona Beach, Florida), 1989

color print, chromogenic development process

image: $33.3 \times 23.1 \mathrm{~cm}$ overall: $35.4 \times 27.7 \mathrm{~cm}$

verso inscription: (black ink): [signed] M. Haven/ 89

\section{Kathleen Collins}

Untitled (Industrial worker in Chicago), c. 1989

color print, chromogenic development process

image: $20.1 \times 19.8 \mathrm{~cm}$ overall: $35.4 \times 27.8 \mathrm{~cm}$

verso inscription: (black ink): [signed] $\mathrm{K}$ Collins

William Peterson

Untitled (Flower in blurry motion), 1989

gelatin silver print

image: 21.8 × $30 \mathrm{~cm}$ overall $27.8 \times 35.4 \mathrm{~cm}$

verso inscription: (pencil): [signed] WR Peterson (C1989/32/35

Ken White

Untitled (Two boulders with puncture holes in sky) c. 1989

gelatin silver print

image: 21.3 x $29.2 \mathrm{~cm}$ overall: $27.5 \times 35.3 \mathrm{~cm}$

verso inscription: (pencil): \#4/35 [signed] Ken White

Willie Osterman

Untitled (Nude woman sitting on rock beside water), 1989

gelatin silver print

image: $25 \times 33 \mathrm{~cm}$ overall: $27.8 \times 35.4 \mathrm{~cm}$

recto inscription: (pencil): [signed] Willie Osterman (C89

John W. Retallack

Untitled (Feet of girl walking by tree with seeds covering the ground), 1989

color print, chromogenic development process

image: 22.3 x $33.3 \mathrm{~cm}$ overall: $27.7 \times 35.5 \mathrm{~cm}$

verso inscription: (black ink on applied label): C1989 JOHN W. RETALLACK 
Jack Holm

Brown Pelicans, 1979

color print, chromogenic development process

image: 23 x $30.5 \mathrm{~cm}$ overall: $27.8 \times 35.5 \mathrm{~cm}$

verso inscription: (black ink): BROWN PELICANS [signed] Jack Holm C1979

Weston Kemp

Untitled (Silhouette of Stonehenge with sun shining between two stones), 1988

color print, chromogenic development process

image: 15.1 x $33.2 \mathrm{~cm}$ overall: $27.7 \times 35.5 \mathrm{~cm}$

verso inscription: (brown ink): (C) [signed] Weston Kemp 1988

Andrew Davidhazy

Untitled (Nude woman squatting and moving in blurred motion), 1989

gelatin silver print

image: 18.4 × $35.1 \mathrm{~cm}$ overall: $27.8 \times 35.4 \mathrm{~cm}$

verso inscription: (black ink): [signed] A Davidhazy ' 89

Skip Battaglia

Untitled (Animation cell from Geologic Time), 1989

art-drawing

image: 15 x $21 \mathrm{~cm}$ overall: $26.6 \times 31.6 \mathrm{~cm}$

recto inscription: (pencil): [underlined] $245.01+02(\mathrm{G}-144)(1=-1 / 5)$

verso inscription: (brown ink): from GEOLOGIC TIME 1989 [signed] Skip Battaglia

John Trauger

Untitled (Man standing next to open door of cabin with two dogs), 1989

gelatin silver print

image: 31.9 × $24.6 \mathrm{~cm}$ overall: $35.4 \times 27.8 \mathrm{~cm}$

recto inscription: (black marker): [signed] John F. Trauger (C)1989

Michael Dear

Untitled (Pond surrounded by vegetation), 1989

color print, chromogenic development process

image: 23.1 x $30.5 \mathrm{~cm}$ overall: $27.7 \times 35.5 \mathrm{~cm}$

verso inscription: (black ink): [signed] Michael E. Dear/ (C)1989

Glenn Miller

Untitled (Close-up of top of green bottle with vines coming out), 1989

color print, chromogenic development process

image: 33.7 x $22.8 \mathrm{~cm}$ overall: 35.4 × $27.7 \mathrm{~cm}$

verso inscription: (black ink): [signed] GCMiller 1989 
Lynne Bentley-Kemp

Untitled (Tree in snow-patched field with sun behind it), 3/19/1989

color print, chromogenic development process

image: $20.5 \times 30.4 \mathrm{~cm}$ overall: $27.8 \times 35.4 \mathrm{~cm}$

verso inscription: (pencil): March 19, 1989 [signed] Lynne Bentley-Kemp

Guenther Cartwright

Rite of Spring, 1989

color print, chromogenic development process

image: 24.2 x $30.7 \mathrm{~cm}$ overall: $27.8 \times 35.5 \mathrm{~cm}$

verso inscription: (blue marker): "RITE OF SPRING" TORONTO CANADA [signed]

Guenther Cartwright 89

Bob Kayser

Untitled (Sun shining through fog with reflection on water), 1989

color print, chromogenic development process

image: $20.5 \times 20.2 \mathrm{~cm}$ overall: $35.5 \times 27.8 \mathrm{~cm}$

recto inscription: (black ink): [signed] R Kayser 1989

Michael Peres

Bursaria x 300, May 1989

color print, chromogenic development process

image: 22.8 × $30.5 \mathrm{~cm}$ overall: $27.7 \times 35.4 \mathrm{~cm}$

verso inscription: (green ink): Bursaria x 300 [signed] Michael R Peres 5/89

Lothar Engelmann

Untitled (magnified organic crystals in polarized light), 1989

color print, silver dye bleach process

image: 34.3 x $26.7 \mathrm{~cm}$ overall: 35.6 x $28 \mathrm{~cm}$

recto inscription: (silver marker): [signed] Lothar Engelmann 1989

Owen Butler

Untitled (Two human figures with tree in foreground), 1989

computer generated

image: 9.2 x $12.1 \mathrm{~cm}$ overall: $27.9 \times 35.6 \mathrm{~cm}$ mount: $12.7 \times 18.2 \mathrm{~cm}$

recto inscription: (blue ink): [signed] OW '89/33

Ira Current

Grace, 1977

gelatin silver print

image: $18.8 \times 28.9 \mathrm{~cm}$ overall: $27.8 \times 34.9 \mathrm{~cm}$

verso inscription: (pencil): Grace/ (black ink): [signed] Ira Current/ [illegible]/ (pencil): 8 384 - [circled] 16/ C1977 


\section{Nancy M. Stuart}

Untitled (Baby with object in his or her mouth sitting on blanket-covered chair), 1989 gelatin silver print image: 19.7 x $19.6 \mathrm{~cm}$ overall: $35.2 \times 27.8 \mathrm{~cm}$ recto inscription: (pencil): (C) Nancy M. Stuart 1989

Amy (Smith) Weiner

Untitled (Roses in vase next to window with silk curtain), c. 1989

gelatin silver print

image: 29.5 x $21.5 \mathrm{~cm}$ overall: $35.4 \times 27.8 \mathrm{~cm}$

recto inscription: (black ink): [signed] Amy Smith

Loret (Falkner) Steinberg

Untitled (Branches sticking out of snow) 1986

computer generated

image: 9.2 x $12.1 \mathrm{~cm}$ overall: $27.9 \times 35.5 \mathrm{~cm}$ mount: $12.7 \times 18.1 \mathrm{~cm}$

recto inscription: (black ink): [signed] Loret Gnivecki Falkner 1986

Denis Defibaugh

Domesticated Unrest, c. 1989

gelatin silver print

image: 13 x $35.3 \mathrm{~cm}$ overall: $27.8 \times 30.7 \mathrm{~cm}$

verso inscription: (pencil) "Domesticated Unrest"/ [signed] Denis Defibaugh

David Joseph

Untitled (Pink seascape), 1989

color print, chromogenic development process

image: $24.1 \times 24.1 \mathrm{~cm}$ overall: $35.4 \times 27.8 \mathrm{~cm}$

verso inscription: (black ink): [signed] David J. Joseph/ (C1989

Mark Watts

Untitled (Photogram of industrial machinery), c. 1989

gelatin silver print

image: 23.8 x $32.1 \mathrm{~cm}$ overall: $27.8 \times 35.2 \mathrm{~cm}$

recto inscription: (black marker): [signed] Mark Watts

Wes Morningstar

Untitled (Close-up of bee on top of daisy with broken petals), c. 1989

color print, chromogenic development process

image: $21.1 \times 30.6 \mathrm{~cm}$ overall: $27.7 \times 35.5 \mathrm{~cm}$

verso inscription: (black ink): (c) [signed] Wes Morningstar 


\section{Rochester Institute of Technology School of Photographic Arts and Sciences Faculty and Staff Portfolio, May 1990}

Howard Lester

Untitled (Two red and green distorted human figures), c. 1990

color print, chromogenic development process

image: 19.9 x $30.5 \mathrm{~cm}$ overall: $27.8 \times 35.5 \mathrm{~cm}$

verso inscription: (black marker): [signed] Howard Lester

Skip Battaglia

Untitled (Outline of hand surrounded by blue), c. 1990

art-drawing

overall: $26.6 \times 31.7 \mathrm{~cm}$

recto inscription: (pencil): 98 only/ [signed] Skip Battaglia

Jack Holm

Approaching Red Mountain Pass, Colorado, 1984

color print, silver dye bleach process

image: 23.4 × $34.9 \mathrm{~cm}$ overall: $27.8 \times 35.5 \mathrm{~cm}$

verso inscription: (black marker): Approaching Red Mountain Pass, Colorado [signed]

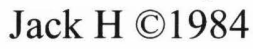

Ken White

Aeroglyphs, Utah, 1983

gelatin silver print

image: $31.5 \times 21.6 \mathrm{~cm}$ overall: $35.4 \times 27.6 \mathrm{~cm}$

verso inscription: (pencil): Aeroglyphs, Utah 1983 29/33 [signed] [illegible] K. W

Andrew Davidhazy

Untitled (Child in headscarf sitting in leaves), 1960

gelatin silver print

image: $22.8 \times 30.5 \mathrm{~cm}$ overall: $27.8 \times 35.5 \mathrm{~cm}$

verso inscription: (black ink): [signed] Davidhazy '60

Lynne Bentley-Kemp

Into the Meadow (published) 1990

gelatin silver print

image: 18.8 × $28.8 \mathrm{~cm}$ overall: $27.9 \times 35.2 \mathrm{~cm}$

verso inscription: (pencil): (C) [signed] Lynne Bentley-Kemp 1990

Glenn Miller

Untitled (Close-up of pink flower with bee on nearby bud), 1990

color print, chromogenic development process

image: 33.1 x $25.2 \mathrm{~cm}$ overall: $35.5 \times 27.8 \mathrm{~cm}$

verso inscription: (black ink): [signed] GCMiller '90 
Michael Dear

Untitled (Cityscape along water at sunset), 1990

color print, chromogenic development process

image: 22.4 x $32.7 \mathrm{~cm}$ overall: 27.7 x $35.4 \mathrm{~cm}$

verso inscription: (black ink): [signed] Michael E Dear/ 1990

Amy (Smith) Weiner

Untitled (Ballet slippers), c. 1990

color print, chromogenic development process

image: 28.4 × $21.4 \mathrm{~cm}$ overall: $35.5 \times 27.9 \mathrm{~cm}$

recto inscription: (black ink): [signed] Amy Weiner

Mark Watts

Pay It Back, Pay It All Back, 1990

multiple processes

image: 21.7 x 28 overall: $27.9 \times 35.5$

recto inscription: (black charcoal): PAY IT BACK/ PAY IT [underlined] ALL BACK/

(black ink): $31 / 50$ [signed] Mark Watts

verso inscription: (stamped): WATTS

Willie Osterman

Untitled (Group of people all holding up cameras), c. 1990

gelatin silver print

image: 9.7 x $34.1 \mathrm{~cm}$ overall: $27.8 \times 35.2 \mathrm{~cm}$

recto inscription: (pencil): [signed] Willie Osterman

verso inscription: (stamped in black ink): CWillie Osterman (pencil): \#29/50

Loret (Falkner) Steinberg

Untitled (Birdseye view of goldfish in pond with reflection of windows), 1990

thermal autochrome

image: 9 × $12 \mathrm{~cm}$ overall: $28 \times 35.5 \mathrm{~cm}$ mount: $10.2 \times 13.2 \mathrm{~cm}$

recto inscription: (black ink): [signed] loret gnivecki falkner 1990

John W. Retallack

Untitled (Broken chair in field with factory in background), 1990

gelatin silver print

image: 24.4 x $24.3 \mathrm{~cm}$ overall: $35.2 \times 27.8 \mathrm{~cm}$

verso inscription: (pencil): (090 JOHN W. RETALLACK

Owen Butler

Untitled (Photographer in front of man posing under studio light), 1990

gelatin silver print

image: $18.1 \times 12.3 \mathrm{~cm}$ overall: $35.4 \times 27.9 \mathrm{~cm}$

recto inscription: (black ink): [signed] OB '90 
William Peterson

Take Off Your Mask, 1990

gelatin silver print

image: 31.1 x $23.1 \mathrm{~cm}$ overall: $35.4 \times 27.8 \mathrm{~cm}$

verso inscription: (pencil): [signed] Will Roger Peterson (C1990/ Self Portrait/ Take Off Your Mask

\section{Michael Peres}

Where Bone Meets Cartilage x 350, c. 1990

color print, chromogenic development process

image: 24.2 x $23.1 \mathrm{~cm}$ overall: $35.4 \times 27.9 \mathrm{~cm}$

verso inscription: (black ink): Where Bone Meets Cartilage X 350 [signed] Michael R.

Peres/ 31

Denis Defibaugh

Untitled (Round stones on top of each other to look like a face), c. 1990

gelatin silver print

image: 30.7 x $24.2 \mathrm{~cm}$ overall: $35.3 \times 27.8 \mathrm{~cm}$

verso inscription: (pencil): [signed] Denis Defibaugh

Wes Morningstar

Untitled (Chinese Dragon), c. 1990

color print, chromogenic development process

image: 19.9 x $29.3 \mathrm{~cm}$ overall: $27.8 \times 35.5 \mathrm{~cm}$

verso inscription: (black ink): (C) [signed] Wes Morningstar

Ira Current

New York Winter, 1985

color print, chromogenic development process

image: 18 x $30.4 \mathrm{~cm}$ overall: $27.9 \times 35.3 \mathrm{~cm}$

verso inscription: (black ink): NEW YORK WINTER/ C1985/ [signed] Ira Current/ K4957/ \#31

John Trauger

Charlie, c. 1990

gelatin silver print

image: $31.8 \times 26.4 \mathrm{~cm}$ overall: $35.3 \times 27.8 \mathrm{~cm}$

recto inscription: (purple ink): Charlie [signed] John F. Trauger

Joan Boccino

The Vision Insulator, 1987

color print, chromogenic development process

image: $24.5 \times 16.3 \mathrm{~cm}$ overall: $35.5 \times 27.7 \mathrm{~cm}$

recto inscription: (black marker): STUDY FOR A VIDEO TAPE/ C 1987 [signed] J Boccino/ "THE VISION INSULATOR"/ (A PRODUCT FOR THE BUSH/HELMS ERA) 


\section{Weston Kemp}

Untitled (Silhouette of Stonehenge with water in foreground), 1990

color print, chromogenic development process

image: 15.7 x $29.3 \mathrm{~cm}$ overall: 27.9 × $35.5 \mathrm{~cm}$

verso inscription: (brown marker): [signed] W. Kemp (C' 90

Nancy M. Stuart

Untitled (Unidentified woman in black sitting), 3/22/1990

gelatin silver print

image: 25.8 x $25.2 \mathrm{~cm}$ overall: $35.2 \times 27.7 \mathrm{~cm}$

recto inscription: (pencil): 3/22/90 (C) Nancy M. Stuart

David Joseph

Untitled (Tent tops in blue), April 1990

color print, chromogenic development process

image: 16.8 x $30.7 \mathrm{~cm}$ overall: 27.8 x $35.5 \mathrm{~cm}$

verso inscription: (black ink): [signed] David J Joseph 4/90

Bob Kayser

Untitled (Two men walking on gravel trail next to building), 1990

color print, chromogenic development process

image: 24.9 x $35.5 \mathrm{~cm}$ overall: 27.9 x $35.5 \mathrm{~cm}$

verso inscription: (black ink): [signed] R Kayser 1990

Dan Larkin

Untitled (Cape Cod), c. 1990

color print, chromogenic development process

image: 26.1 x $26.1 \mathrm{~cm}$ overall: 35.4 x $27.8 \mathrm{~cm}$

recto inscription: (black ink): [signed] Dan Larkin

Amy Friend

Untitled (Blue Jellyfish), c. 1990

color print, chromogenic development process

overall: $35.5 \times 27.8 \mathrm{~cm}$

unsigned

\section{Rochester Institute of Technology School of Photographic Arts and Sciences Faculty and Staff Portfolio, May 1991}

John Trauger

Phoebe Shaw Special, 1938

gelatin silver print

image: 32.9 × $25.1 \mathrm{~cm}$ overall: 35.4 × $27.8 \mathrm{~cm}$

recto inscription: (black ink): Phoebe Shaw Special 1938 [signed] John F Trauger 
Michael Dear

Untitled (Rollercoaster in snow-covered field next to fence and trees covered in ice), c.

1991

color print, chromogenic development process

image: 11.4 x $32.3 \mathrm{~cm}$ overall: 27.8 x $35.5 \mathrm{~cm}$

unsigned

Elaine O'Neil

Untitled (Life-size cut-outs of characters with woman on bench in background), c. 1987 (1991)

gelatin silver print

image: 22 x $32.9 \mathrm{~cm}$ overall: $27.2 \times 35.5 \mathrm{~cm}$

verso inscription: (pencil): [signed] Elaine O'Neil/ 1987/91/ 13/34/

Stephen J. Diehl

Richardson Highway Near Fairbanks, Alaska, 1991

color print, silver dye bleach process

image: $33.5 \times 22.1 \mathrm{~cm}$ overall: $35.5 \times 27.9 \mathrm{~cm}$

verso inscription: (black marker): (C) [signed] Stephen J. Diehl, 1991 Richardson

Highway Near Fairbanks, Alaska

Skip Battaglia

Untitled (Abstract drawing in red, orange and blue), c. 1991

art-drawing

image: 8.5 x $13.9 \mathrm{~cm}$ overall: $24.1 \times 31.8 \mathrm{~cm}$

recto inscription: (pencil): $388.23=24 / 47$ (D-5)2/ (brown ink): [signed] Skip Battaglia

Amy (Smith) Weiner

Untitled (Lily pads in water), c. 1991

color print, chromogenic development process

image: 21.2 x $29.7 \mathrm{~cm}$ overall: $27.8 \times 35.4 \mathrm{~cm}$

verso inscription: (black ink): [signed\} Amy Weiner

Owen Butler

Untitled (Man on bench in park viewed from high angle through trees), 1991

gelatin silver print

image: $15 \times 22.2 \mathrm{~cm}$ overall: $27.8 \times 35.4 \mathrm{~cm}$

recto inscription: (black ink): [signed] Owen Butler ' 91

Joan Boccino

Things Were Not as They Seemed, 1991

gelatin silver print

image: 25.2 x $25.2 \mathrm{~cm}$ overall: 35.4 x $27.8 \mathrm{~cm}$

recto inscription: (black ink): (C1991 [signed] Joan Boccino/ "Things were not as They seemed" 


\section{Andrew Davidhazy}

Stroebel and Francis, 1984

gelatin silver print

image: 19.8 x $34.4 \mathrm{~cm}$ overall: $27.8 \times 35.5 \mathrm{~cm}$

recto inscription: (pencil): Stroebel + Francis [signed] Davidhazy 1984

Includes instruction sheet with diagram on how to view the image

Howard Lester

Untitled (Man in uniform standing next to light pole at night) c. 1991

color print, chromogenic development process

image: 25.5 x $35.3 \mathrm{~cm}$ overall: $27.8 \times 35.4 \mathrm{~cm}$

recto inscription: (black ink): Howard Lester

John W. Retallack

Untitled (Blurry speed limit sign in front of trees), 1991

color print, chromogenic development process

image: 18.9 x $26.1 \mathrm{~cm}$ overall: $27.8 \times 35.4 \mathrm{~cm}$

recto inscription: (black ink): JWR '91

verso inscription: (black marker): (C1991 John W. Retallack

Lynne Bentley-Kemp

Truman Annex, Key West, Florida, March 1991

gelatin silver print

image: 19.3 x $29.5 \mathrm{~cm}$ overall: $27.7 \times 35.2 \mathrm{~cm}$

verso inscription: (pencil): Truman Annex - Key West, Fla. Mar. 1991 [signed] Lynne

Bentley-Kemp

Michael Peres

Untitled (Close-up of cell), May 1991

gelatin silver print

image: 25.6 × $25.4 \mathrm{~cm}$ overall: $35.5 \times 27.6 \mathrm{~cm}$

recto inscription: (pencil): [signed] Michael R Peres 5/91

William DuBois

Untitled (Staircase with spiral columns), 1991

gelatin silver print

image: $20.3 \times 17.9 \mathrm{~cm}$ overall: $35.2 \times 27.9 \mathrm{~cm}$

verso inscription: (pencil): [signed] William W DuBois '91

Nancy M. Stuart

J.B., 1991

gelatin silver print

image: 25.6 x $20.2 \mathrm{~cm}$ overall: $35.3 \times 27.8 \mathrm{~cm}$

recto inscription: (embossed stamp): ALL RIGHTS RESERVED/ NMS/ NANCY M.

STUART

verso inscription: (pencil): J.B. 1991 
Dan Larkin

Untitled (Cape Cod), c. 1991

color print, chromogenic development process

image: 20.3 x $20.3 \mathrm{~cm}$ overall: 35.4 x $27.8 \mathrm{~cm}$

verso inscription: (black ink): [signed] Dan Larkin

David Joseph

Untitled (Group of policemen with helmets and batons blurry from movement), c. 1991 color print, chromogenic development process

image: 12.8 x $30.4 \mathrm{~cm}$ overall: $27.9 \times 35.4 \mathrm{~cm}$

verso inscription: (black ink): [signed] David J Joseph

Loret (Falkner) Steinberg

Untitled (Trees next to water seen through haze), c. 1991

computer generated

image: 9.2 x $12.2 \mathrm{~cm}$ overall: $35.5 \times 27.9 \mathrm{~cm}$ mount: $12.8 \times 18.1 \mathrm{~cm}$

recto inscription: (black ink): [signed] Loret Gnivecki Falkner

Mark Sager

Catskills, 1991

color print, chromogenic development process

image: 22.9 × $35 \mathrm{~cm}$ overall: $27.8 \times 35.5 \mathrm{~cm}$

recto inscription: (black ink): Catskills [signed] Mark D Sager '91

Bob Kayser

Untitled (Wife sitting at far end of porch with empty chairs near her), 1991

color print, chromogenic development process

image: $23 \times 15.2 \mathrm{~cm}$ overall: $35.5 \times 27.8 \mathrm{~cm}$

recto inscription: (blue ink): [signed] R. Kayser 1991

Ken White

Montmartre Cemetery, Paris, 1990

gelatin silver print

image: 24.2 x $31.8 \mathrm{~cm}$ overall: $27.9 \times 35.5 \mathrm{~cm}$

recto inscription: (black marker): Montmartre Cem. PARIS 1990 22/27 K. White

Glenn Miller

Untitled (Three pilots in gear in front of plane), c. 1991

color print, chromogenic development process

image: 22.7 x $17.8 \mathrm{~cm}$ overall: $35.4 \times 27.8 \mathrm{~cm}$

recto inscription: (black ink): [signed] GCMiller 
Wes Morningstar

Untitled (Shirtless man with goatee on deck with cacti), c. 1991

gelatin silver print

image: 17.8 x $25.5 \mathrm{~cm}$ overall: $27.8 \times 35.4 \mathrm{~cm}$

verso inscription: (black ink): (c) [signed] Wes Morningstar

\section{Rochester Institute of Technology School of Photographic Arts and Sciences Faculty and Staff Portfolio, May 1992}

John Trauger

Trauger Homestead, Revere, Pennsylvania, c. 1992

gelatin silver print

image: 32.8 x $24.1 \mathrm{~cm}$ overall: $35.4 \times 27.8 \mathrm{~cm}$

recto inscription: (black ink): [signed] J Trauger

verso inscription: (applied printed label): FAMILY ARCHIEVES SERIES/ TRAUGER

HOMESTEAD/ REVERE PENNSYLVANIA 1910/ By John F. Trauger

Elaine O'Neil

Untitled (Skeleton of gaboon viper in cage), 1980

gelatin silver print

image: $20.5 \times 30.5 \mathrm{~cm}$ overall: $27.8 \times 35.4 \mathrm{~cm}$

verso inscription: (pencil): [signed] Elaine O'Neil/ 1980

William DuBois

Untitled (Blurry train going over tracks), 1992

gelatin silver print

image: $19.1 \times 18.9 \mathrm{~cm}$ overall: $35.6 \times 27.7 \mathrm{~cm}$

verso inscription: (pencil): [signed] William W DuBois, 1992

Nancy M. Stuart

Untitled (Self-portrait of pregnant belly next to daughter rubbing her eye), c.1992

gelatin silver print

image: $16.1 \times 16.3 \mathrm{~cm}$ overall: $35.2 \times 27.8 \mathrm{~cm}$

recto inscription: (embossed stamp): ALL RIGHTS RESERVED/ NMS/ NANCY M

STUART

Skip Battaglia

Untitled (film cell from Restlessness), c. 1992

multiple processes

image: 18.6 x $26.8 \mathrm{~cm}$ overall: 26.1 x $31.7 \mathrm{~cm}$ mount: $21.5 \times 27.8 \mathrm{~cm}$

recto inscription: (black ink): 48. (white paint): [signed] Battaglia 
Bob Kayser

Untitled (Window in stone wall with wooden shutters seen through window frames), 1992

color print, chromogenic development process

image: 27.9 x $17.7 \mathrm{~cm}$ overall: 35.5 x $27.8 \mathrm{~cm}$

recto inscription: (black ink): [signed] R. Kayser 1992

Dan Larkin

Untitled (Blurry close-up of green pepper on pink background) c. 1992

color print, chromogenic development process

image: 25.8 x $25.6 \mathrm{~cm}$ overall: 35.4 x $27.9 \mathrm{~cm}$

recto inscription: (black ink): [signed] Dan Larkin

Ira Current

Road to Winter, 1977

color print, chromogenic development process

image: $25.6 \times 25.3 \mathrm{~cm}$ overall: $27.8 \times 35.4 \mathrm{~cm}$

verso Inscription: (blue ink): ROAD TO WINTER/ [signed] Ira Current/ 32970/ 1969/

(C) 1977 \#41

Mark Watts

Monument (Safety), 1992

computer generated

image: 24.3 x $25.3 \mathrm{~cm}$ overall: $35.6 \times 27.9 \mathrm{~cm}$

recto inscription: (black ink): 10 (printed): /30 M. Watts 1992/ (black ink): [signed] Mark

Watts

Mark Sager

Untitled (Firemen and hoses in street next to burning house, one fireman looking at

photographer), 1992

color print, chromogenic development process

image: 16.7 x $34.8 \mathrm{~cm}$ overall: 27.9 x $35.4 \mathrm{~cm}$

recto Inscription: (black marker): [signed] Mark D Sager '92

Michael Dear

Untitled (Forest covered in ice), 1992

color print, chromogenic development process

image: 12.7 x $34 \mathrm{~cm}$ overall: 27.8 × $35.4 \mathrm{~cm}$

recto inscription: (black ink): [signed] Michael E. Dear 92

Michael Peres

Untitled (Close-up of cells), 1992

color print, chromogenic development process

image: 23.1 x $23.1 \mathrm{~cm}$ overall: $35.5 \times 27.8 \mathrm{~cm}$

verso inscription: (blue ink): [signed] Michael R Peres 1992 
Ken White

Mancos, Colorado, 1990

gelatin silver print

image: 29.2 × $21.5 \mathrm{~cm}$ overall: $35.3 \times 27.7 \mathrm{~cm}$

recto inscription: (black marker): Mancos, CO 1990

Stephen J. Diehl

Newfoundland, 1991

color print, silver dye bleach process

image: 33.3 x $24.4 \mathrm{~cm}$ overall: 35.3 x $27.8 \mathrm{~cm}$

verso inscription: (black ink): [signed] Stephen J. Diehl/ Newfoundland 1991

Lynne Bentley-Kemp

Staghorn Fern, c. 1992

gelatin silver print

image: 21 x $31.9 \mathrm{~cm}$ overall: $35.3 \times 27.7 \mathrm{~cm}$

recto inscription: (pencil): Staghorn fern [signed] Lynne Bentley Kemp

David Joseph

Untitled (Panoramic of lake with docks and houses on shore), c. 1992

color print, chromogenic development process

image: 10.1 x $30.6 \mathrm{~cm}$ overall: $27.9 \times 35.4 \mathrm{~cm}$

verso inscription: (black ink): David J Joseph

Guenther Cartwright

Buffalo, New York, 1992

color print, chromogenic development process

image: 25 x $30.6 \mathrm{~cm}$ overall: $27.9 \times 35.4 \mathrm{~cm}$

recto inscription: (blue ink): [signed] Guenther Cartwright BUFFALO, NY, 1992

Jodi Baker

Untitled (Two boys and one girl laughing), c. 1992

gelatin silver print

image: 25.5 x $25.3 \mathrm{~cm}$ overall: 35.4 × $27.8 \mathrm{~cm}$

verso inscription: (pencil): [signed] Jodi Baker

in acetate

Denis Defibaugh

Untitled (Hispanic family and chickens next to wall), 1992

color print, chromogenic development process

image: 13.3 x $33.1 \mathrm{~cm}$ overall: $27.9 \times 35.4 \mathrm{~cm}$

verso inscription: (black ink): [signed] Denis Defibaugh 1992 
John W. Retallack

Khrushchev's Head, c. 1992

color print, chromogenic development process

image: 30.7 x $20.8 \mathrm{~cm}$ overall: $35.5 \times 27.8 \mathrm{~cm}$

recto inscription: (black marker): KHRUSHCHEV'S HEAD RETALLACK

Andrew Davidhazy

Untitled (C-shaped panoramic of colorful buildings), 1991

color print, chromogenic development process

image: 21.7 x $21.6 \mathrm{~cm}$ overall: $35.5 \times 27.8 \mathrm{~cm}$

verso inscription: (gold marker): [signed] Davidhazy/ 91

J. Tomas (Thomas) Lopez

Untitled (Human figure laying underwater), c. 1992

gelatin silver print

image: 21.5 x $30.2 \mathrm{~cm}$ overall: $27.9 \times 35.4 \mathrm{~cm}$

recto inscription: (black ink): [signed] J. Tomas Lopez

Wes Morningstar

Untitled (Close-up of plant), 1992

gelatin silver print

image: 25.4 x $17.8 \mathrm{~cm}$ overall: $35.4 \times 27.8 \mathrm{~cm}$

verso inscription: (pencil): (C) [signed] Wes Morningstar, 1992

Glenn Miller

Untitled (Sun behind clouds reflecting on water), 1992

color print, chromogenic development process

image: 26.4 x $17.7 \mathrm{~cm}$ overall: $35.4 \times 27.8 \mathrm{~cm}$

verso inscription: (black ink): [signed] GCMiller 1992

William Fischer

Untitled (Panoramic of two close-up eyeballs), 1992

gelatin silver print

image: 12.4 x $34.3 \mathrm{~cm}$ overall: $27.9 \times 35.3 \mathrm{~cm}$

verso inscription: (pencil): [signed] William Fischer '92 


\section{Bibliography}

Buck, Rebecca A., and Jean Allman Gilmore, eds. The New Museum Registration Methods. Washington DC: American Association of Museums, 1998.

Casal, Robert and Dominique Schnapper. "Aesthetic Ambitions and Social Aspirations: The Camera Club as a Secondary Group," in Photography: A Middle-brow Art by Pierre Bourdieu, translated by Shaun Whiteside. Stanford, CA: Stanford University Press, 1965.

Gordon, Dane R. Rochester Institute of Technology: Industrial and Educational Innovation in an American City 1829-2006, $2^{\text {nd }}$ ed. Rochester, NY: RIT Press, 2007.

Lyons, Nathan. "History of Photographic Education with an Emphasis on its Development in the United States." In The Education of a Photographer, edited by Steven Heller and Adam B. Bell, 177-184. New York: Allworth Press, 2006.

Peres, Michael R., ed. The Focal Encyclopedia of Photography: Digital Imaging, Theory and Applications, History and Science, $4^{\text {th }}$ ed. New York: Focal, 2007.

Phoenix, Allan David. "Preparing An Acquisition Report for The Portfolio, F. Frith's Photo-Pictures of the Lands of the Bible Illustrated by Scripture Words." master's thesis, Ryerson University, 2008.

Shoemaker, William Soule. History of The School of Photographic Arts and Sciences: Prepared in Honor of the $50^{\text {th }}$ Anniversary of the Founding of that School. Rochester, NY: RIT, 1980.

Sobieszek, Robert and Joan Pedzich. Rochester: An American Center of Photography. Rochester, NY: International Museum of Photography at George Eastman House, 1984.

Stuart, Nancy M. "The History of Photographic Education in Rochester, New York, 1960-1980." PhD diss., State University of New York at Buffalo, 2005. 